\title{
New Insights into the Partitioning of Phenothiazine Dyes in Aqueous Two-Phase Systems
}

\author{
Yara L. Coelho, ${ }^{a}$ Álvaro J. P. Agudelo, ${ }^{a, b}$ Guilherme M. D. Ferreira, ${ }^{c}$ Gabriel M. D. Ferreira, ${ }^{d}$ \\ Alan S. B. de Castro, ${ }^{a}$ Eliara A. Hudson, ${ }^{e}$ Ana Clarissa S. Pires ${ }^{e}$ and Luis H. M. da Silva ${ }^{\circledR *, a}$ \\ ${ }^{a}$ Grupo de Química Verde Coloidal e Macromolecular (QUIVECOM), Departamento de Química, \\ Universidade Federal de Viçosa, Av. PH Rolfs, s/n, 36570-900 Viçosa-MG, Brazil \\ ${ }^{b}$ Instituto de Química, Universidade de São Paulo, Av. Lineu Prestes 748, Cidade Universitária, \\ 05508-000 São Paulo-SP, Brazil \\ 'Departamento de Química, Universidade Federal de Lavras, Campus Universitário, \\ 37200-000 Lavras-MG, Brazil \\ ${ }^{d}$ Departamento de Química, Universidade Federal de Ouro Preto, Campus Universitário, \\ 35400-000 Ouro Preto-MG, Brazil
}

${ }^{e}$ Grupo de Termodinâmica Molecular Aplicada (THERMA), Departamento de Tecnologia de Alimentos, Universidade Federal de Viçosa, Av. PH Rolfs, s/n, 36570-900 Viçosa-MG, Brazil

\begin{abstract}
Aqueous two-phase systems (ATPSs) have proven to be efficient and environmentally safe methods for extracting chemical species. However, the driving forces behind the partition of solutes in these systems are still little understood. A complete thermodynamic partitioning of phenothiazine dyes was investigated in poly (ethylene oxide) (PEO) + salt + water ATPSs. Standard transfer parameters (Gibbs free energy change $\left(\Delta_{\mathrm{tr}} \mathrm{G}^{\circ}\right)$, enthalpy change $\left(\Delta_{\mathrm{tr}} \mathrm{H}^{\circ}\right)$ and entropy change $\left(\mathrm{T} \Delta_{\mathrm{tr}} \mathrm{S}^{\circ}\right)$ ) were evaluated, and their dependence on the dye structure, electrolyte nature and tie line length (TLL). All phenothiazine dyes are concentrated predominantly in the polymer enriched phase, with $\Delta_{\mathrm{tr}} \mathrm{G}^{\mathrm{o}}$ values ranging from -4.1 up to $-13.4 \mathrm{~kJ} \mathrm{~mol}^{-1}$. Due to the dye-PEO attractive interactions that occur mainly via benzene condensed ring present in the structures of phenothiazine dyes, the partitioning of these dyes was enthalpically driven, with $-11.4 \geq \Delta_{\mathrm{tr}} \mathrm{H}^{\circ} \geq-52 \mathrm{~kJ} \mathrm{~mol}^{-1}$ and $-4.93 \geq \mathrm{T} \Delta_{\mathrm{tr}} \mathrm{S}^{\circ} \geq-38 \mathrm{~kJ} \mathrm{~mol}^{-1}$.
\end{abstract}

Keywords: aqueous two-phase system, thermodynamic, phenothiazine dye, partition, driving force

\section{Introduction}

Since 1958 with the pioneering work of Albertson, ${ }^{1}$ aqueous two-phase systems (ATPS) have proven to be efficient and environmentally safe methods for the extraction and purification of a great number of chemical species, such as enzymes, ${ }^{2}$ proteins, ${ }^{3}$ metals, ${ }^{4,5}$ nanoparticles, ${ }^{6}$ carbon nanotubes, ${ }^{7}$ and synthetic ${ }^{8-13}$ and natural ${ }^{14-16}$ dyes. Despite these works, most of the studies ${ }^{9,17-21}$ investigating the partitioning of solutes have been limited to investigating the feasibility of utilizing aqueous two-phase extraction for the separation and purification of the solutes. There are few studies that demonstrate a systematic thermodynamic approach that enables the comprehension of the driving

*e-mail: luhen@ufv.br forces governing the transfer process of these solutes in an ATPS, mainly due to the difficulty in obtaining direct measurements for values of standard enthalpy change $\left(\Delta_{\mathrm{tr}} \mathrm{H}^{\circ}\right)$ during a solute transfer.

Da Silva et al. ${ }^{22}$ in 2008 , determined the solution enthalpies for the partition of $\left[\mathrm{Fe}(\mathrm{CN})_{5}(\mathrm{NO})\right]^{2-}$ and $\left[\mathrm{Fe}(\mathrm{CN})_{6}\right]^{3-}$ ions in ATPSs formed by triblock copolymers and phosphate salts, using calorimetric measurements by the ampoule breaking technique. They showed that the transfer process of these anions is exothermic and enthalpically driven. Posteriorly, Mageste et al. ${ }^{14}$ in 2012, evaluated the partition of the natural dye norbixin in different ATPSs formed with polymer/copolymer and salt, using isothermal titration calorimetry to determine the $\Delta_{\mathrm{tr}} \mathrm{H}^{\circ}$. This method consisted in the simulation of the ATPS inside the calorimetry sample cell, and the flow 
energy of this process was numerically equal to the enthalpy change of the system. Similar to the results obtained in da Silva et al. ${ }^{22}$ work, the norbixin partitioning in the ATPS also releases energy during the transfer process, with values of transfer enthalpy change varying between $-2.7 \pm 0.3$ and $-9.1 \pm 0.5 \mathrm{~kJ} \mathrm{~mol}^{-1}$. However, the exothermicity of the transfer process of solutes obtained by calorimetric methods is not a general trend. Alcântara et al., ${ }^{23}$ in 2014, using a calorimetric experimental approach similar to Mageste et al. ${ }^{14}$ work, studied the $\alpha$-lactalbumin ( $\alpha$-la) partition in an ATPS containing poly(ethylene glycol) and sodium polyacrylate, reporting the process to be enthalpy unfavorable and entropically driven.

A work involving the complete thermodynamics of a solute partition using isothermal titration calorimetry (ITC) was published in 2016 by Rengifo et al. ${ }^{24}$ where it was studied the driving forces for the partition of chymosin in all tie line lengths (TLLs) in poly(ethylene oxide) (PEO) PEO $1500+\mathrm{LiSO}_{4}+$ water ATPS. In this work, the thermodynamic parameters were obtained for the first time at an infinite dilution state, a more rigid calorimetric approach to determine accurately the $\Delta_{\mathrm{tr}} \mathrm{H}^{\infty}$. The results obtained in this paper showed that the partition process was enthalpically driven $\left(-4.84 \geq \Delta \mathrm{H}_{\text {tr.Chy }}^{\infty} \geq-170.34 \mathrm{~kJ} \mathrm{~mol}^{-1}\right)$ and entropically unfavorable $\left(-11.69 \geq \Delta \mathrm{S}_{\text {tr.Chy }}^{\infty} \geq-558.95 \mathrm{~J} \mathrm{~mol}^{-1} \mathrm{~K}^{-1}\right)$.

In view of the low number of thermodynamic studies describing the driving forces for solute distribution in ATPSs, a systematic thermodynamic approach from an experimental point of view becomes necessary. A strategic approach for studying the driving forces that determine the partition behavior of solutes in an ATPS is to evaluate the partition behavior of chemical compounds with similar chemical structures, using them as molecular probes.

An example of these structurally similar compounds is the phenothiazine dyes. These dyes have the same phenothiazine skeleton, differing only in the $\mathrm{CH}_{3}$ groups present in their chemical structures, which makes them excellent probes to evaluate the partition behavior in ATPSs. In addition to these structural characteristics, phenothiazine dyes have a variety of biological activities, and have been widely used as therapeutic agents in the treatment of many diseases, ${ }^{25-29}$ which makes it even more strategic to study the partition behavior of these compounds, as well as its extraction by ATPSs.

Therefore, in this work, the phenothiazine dyes, such as methylene blue (MB), azure B (AZB), azure A (AZA), and thionin acetate (TA) (Figure S1, Supplementary Information (SI) section) are used as probes to evaluate the nature of the interactions associated with dye partitioning in ATPSs. We determine the transfer thermodynamic parameters for the several dyes and their dependence on the following ATPS properties: TLL values, cation and anion structures.

\section{Experimental}

\section{Materials}

PEO with a molar mass of $1500 \mathrm{~g} \mathrm{~mol}^{-1}$ (CAS No. 25322-68-3) was purchased from Synth (Diadema, Brazil). The inorganic salts sodium sulfate (CAS No. 7757-82-6), magnesium sulfate heptahydrate (CAS No. 10034-99-8), and lithium sulfate (CAS No. 10377-48-7), and the organic salts sodium tartrate dihydrate (CAS No. 6106-24-7), and sodium citrate dihydrate (CAS No. 6132-04-3), were all purchased from Vetec (Duque de Caxias, Brazil). The dyes MB (CAS No. 122965-43-9), AZB (CAS No. 531-55-5), AZA (CAS No. 531-53-3), and TA (CAS No. 78338-22-4) were purchased from Sigma-Aldrich (Saint Louis, USA). Deionized water was used in all experiments. In Table 1, the purity of these chemicals are represented. All chemicals utilized in this study were used without further purification.

Table 1. A brief summary of the purity of the used materials

\begin{tabular}{lccc}
\hline Material & Source & Molecular formula & Mass fraction purity / \% \\
\hline Poly(ethylene oxide) & Synth & $\mathrm{HO}_{\left(\mathrm{CH}_{2} \mathrm{CH}_{2} \mathrm{O}\right)_{\mathrm{n}} \mathrm{H}}$ & 100 \\
Magnesium sulfate heptahydrate & Vetec & $\mathrm{MgSO}_{4} \cdot 7 \mathrm{H}_{2} \mathrm{O}$ & 100 \\
Sodium sulfate & Vetec & $\mathrm{Na}_{2} \mathrm{SO}_{4}$ & 99 \\
Lithium sulfate & Vetec & $\mathrm{Li}_{2} \mathrm{SO}_{4}$ & 99 \\
Sodium tartrate & Vetec & $\mathrm{Na}_{2} \mathrm{C}_{4} \mathrm{H}_{4} \mathrm{O}_{6} \cdot 2 \mathrm{H}_{2} \mathrm{O}$ & 99.5 \\
Sodium citrate & Vetec & $\mathrm{Na}_{3} \mathrm{C}_{6} \mathrm{H}_{5} \mathrm{O}_{7} \cdot 2 \mathrm{H}_{2} \mathrm{O}$ & 99 \\
Methylene blue & Sigma-Aldrich & $\mathrm{C}_{16} \mathrm{H}_{18} \mathrm{ClN}_{3} \mathrm{~S}$ & $\geq 82$ \\
Azure B & Sigma-Aldrich & $\mathrm{C}_{15} \mathrm{H}_{16} \mathrm{ClN}_{3} \mathrm{~S}$ & $\geq 89$ \\
Azure A & Sigma-Aldrich & $\mathrm{C}_{14} \mathrm{H}_{14} \mathrm{ClN}_{3} \mathrm{~S}$ & ca. 80 \\
Thionin acetate & Sigma-Aldrich & $\mathrm{C}_{12} \mathrm{H}_{9} \mathrm{~N}_{3} \mathrm{~S}_{2} \cdot \mathrm{C}_{2} \mathrm{H}_{4} \mathrm{O}_{2}$ & $\geq 85$ \\
\hline
\end{tabular}


Preparation of aqueous two-phase systems and determination of partition coefficients for dyes (MB, AZA, AZB and TA)

The compositions of the ternary mixtures of the ATPSs used in the partitioning experiments were chosen based on the phase diagrams previously published. ${ }^{30,31}$ To achieve the desired compositional ratio for each ATPS, appropriate amounts of water, PEO and salt solutions were taken into graduated centrifuge tubes. The tubes were shaken and left to stand at $25.0{ }^{\circ} \mathrm{C}$, in a thermostatic bath (Microquimica, MQBTC 99-20), with an uncertainty of $\pm 0.1{ }^{\circ} \mathrm{C}$.

Once the system had achieved thermodynamic equilibrium, the two phases were collected separately for the partitioning experiments. A total of $3.0 \mathrm{~g}$ of each phase was mixed with $60 \mu \mathrm{L}$ of the phenothiazine dye solution stock $\left(3.5 \mathrm{mmol} \mathrm{kg}{ }^{-1}\right)$ in glass tubes. The resultant concentration of the investigated dyes in the tubes was $35 \mu \mathrm{mol} \mathrm{kg} \mathrm{kg}^{-1}$. For each TLL and each ATPS, three systems were prepared: the first was a blank without the addition of the dye, the second was a sample, and the third was a replica. These systems were stirred manually for $3 \mathrm{~min}$ until the solutions became cloudy and then they were maintained under controlled temperature in a thermostatic bath at $25^{\circ} \mathrm{C}$ for a minimum of $24 \mathrm{~h}$ to allow them reach thermodynamic equilibrium. Aliquots of the top and the bottom phases were collected with a syringe and adequately diluted with deionized water for a spectrophotometric analysis at 664 (MB), 652 (AZB), 637 (AZA) and $604 \mathrm{~nm}$ (TA) using a Shimadzu digital double beam spectrometer (UV-2550) at $25^{\circ} \mathrm{C}$.

The phenothiazine dye partition coefficients $(\mathrm{K})$ between the phases were determined by the concentration ratio of the analyte in each phase of the ATPS. In agreement with the Beer-Lambert law, the absorbance of the analyte at a specific wavelength is directly proportional to the dye concentration in dilute systems, where dimers are not formed. Thus, the $\mathrm{K}$ can be given as described in equation 1 .

$K=\frac{\left(\mathrm{Abs}^{\mathrm{T}}\right) \times(\mathrm{fd})^{\mathrm{T}}}{\left.(\mathrm{Abs})^{\mathrm{B}}\right) \times(\mathrm{fd})^{\mathrm{B}}}$

where $\mathrm{Abs}^{\mathrm{T}}$ and $\mathrm{Abs}^{\mathrm{B}}$ are the dyes absorbances in diluted top and bottom phases, respectively, discounting the absorbance of the corresponding blanks, and $\mathrm{fd}^{\mathrm{T}}$ and $\mathrm{fd}^{\mathrm{B}}$ are the dilution factors in each phase.

$\mathrm{K}$ was studied for the different TLL values of each ATPS investigated. The TLL numerically expresses the difference in the intensive thermodynamic functions between the top and the bottom phases, at constant pressure and temperature. It is calculated using equation $2::^{24}$
$\mathrm{TLL}=\sqrt{\left(\mathrm{C}_{\mathrm{p}}^{\mathrm{T}}-\mathrm{C}_{\mathrm{p}}^{\mathrm{B}}\right)^{2}+\left(\mathrm{C}_{\mathrm{s}}^{\mathrm{T}}-\mathrm{C}_{\mathrm{s}}^{\mathrm{B}}\right)^{2}}$

where $\mathrm{C}_{\mathrm{p}}{ }^{\mathrm{T}}$ and $\mathrm{C}_{\mathrm{p}}{ }^{\mathrm{B}}$ are the polymer concentrations $(\% \mathrm{~m} / \mathrm{m})$ in the top and bottom phases, respectively, and $\mathrm{C}_{\mathrm{s}}{ }^{\mathrm{T}}$ and $\mathrm{C}_{\mathrm{s}}{ }^{\mathrm{B}}$ are the corresponding salt concentrations $(\% \mathrm{~m} / \mathrm{m})$ in the top and bottom phases, respectively.

\section{Thermodynamic parameters of dye transfer}

Dye transfer standard Gibbs free energy change $\left(\Delta_{\mathrm{tr}} \mathrm{G}^{\circ}\right)$

The standard Gibbs free energy change of transfer $\left(\Delta_{\mathrm{tr}} \mathrm{G}^{\mathrm{o}}\right)$ is the change in the Gibbs energy of the system when $1 \mathrm{~mol}$ of dye, at infinite dilution is transferred from the bottom to the top phase. For all ATPSs studied, the $\Delta_{t r} G^{o}$ was obtained following the thermodynamic relationship:

$\Delta_{\text {tr }} \mathrm{G}^{\mathrm{o}}=-\mathrm{RT} \ln \mathrm{K}$

where $\mathrm{R}$ is the ideal gas constant and $\mathrm{T}$ is the absolute temperature; $\mathrm{K}$ is the partition coefficient of the dye.

\section{Dye transfer standard enthalpy change $\left(\Delta_{\mathrm{tr}} \mathrm{H}^{\circ}\right)$}

Isothermal titration calorimetry (ITC) was used to determine the $\Delta_{\mathrm{tr}} \mathrm{H}^{\circ}$ of the dye from the bottom phase to the top phase of the system. The experiments were conducted in a microcalorimeter CSC-4200 (Science Corp. Calorimeter).

The $\Delta_{\mathrm{tr}} \mathrm{H}^{\circ}$ values for $\mathrm{MB}, \mathrm{AZB}$ and AZA (calorimetric experiment for the dye TA was not possible due to its precipitation in the system) in each TLL were obtained through the following steps: the energy associated with the dilution process $\left(\mathrm{H}_{\mathrm{ob}}^{\mathrm{dil}}\right)$ was determined by filling the reference and the sample cells with $1.80 \mathrm{~mL}$ of the bottom (or top) phase, and titrating the sample solution with fifteen consecutive injections of $15 \mu \mathrm{L}$ of dye at a concentration of $0.5 \mathrm{mmol} \mathrm{kg} \mathrm{kg}^{-1}$ injected into the bottom (or top) phase of the ATPS. To discount the energy associated with friction effects $\left(\mathrm{H}_{\mathrm{ob}}^{\mathrm{f}}\right)$, the same experiment was performed in the absence of the dyes. A gastight Hamilton syringe $(250 \mu \mathrm{L})$ controlled by an instrument was utilized for the injections, and a stirrer helix stirring at $300 \mathrm{rpm}\left(\mathrm{s}^{-1}\right)$ was used throughout the experiment.

The values of excess enthalpy $\left(\mathrm{H}_{\text {dye }}^{\mathrm{E}}\right)$ obtained for each injection were calculated using equation 4 below:

$\mathrm{H}_{\mathrm{dye}}^{\mathrm{E}}=\frac{\mathrm{H}_{\mathrm{ob}}^{\mathrm{dil}}-\mathrm{H}_{\mathrm{ob}}^{\mathrm{f}}}{\mathrm{n}}$

where $\mathrm{n}$ is the number of moles of the dye after each injection.

The $\mathrm{H}_{\text {dye }}^{\mathrm{E}}$ was plotted as a function of the dye concentration (represented henceforth as [dye]), and the 
values of the excess enthalpy of MB, AZB, and AZA dyes at infinite dilution conditions $\left(\mathrm{H}_{\mathrm{dye}}^{\mathrm{E}, \infty}\right)$ were calculated by extrapolating the $\mathrm{H}_{\mathrm{dye}}^{\mathrm{E}}$ versus [dye] curve to zero. Then, the $\Delta_{\mathrm{tr}} \mathrm{H}^{\circ}$ values were obtained by using the following equation:

$\Delta_{\text {tr }} \mathrm{H}^{\mathrm{o}}=\mathrm{H}_{\text {dye-TP }}^{\mathrm{E}, \infty}-\mathrm{H}_{\text {dye-BP }}^{\mathrm{E}, \infty}$

where $\mathrm{H}_{\mathrm{dye}-\mathrm{TP}}^{\mathrm{E}, \infty}$ and $\mathrm{H}_{\mathrm{dye}-\mathrm{BP}}^{\mathrm{E}, \infty}$ are the excess enthalpy of dyes at infinite dilution in top and bottom phases, respectively.

\section{Dye transfer standard entropy change $\left(\Delta_{\mathrm{tr}} \mathrm{S}^{\circ}\right)$}

The $\Delta_{\mathrm{tr}} S^{\circ}$ values were determined from the following classic thermodynamic relationship:

$\Delta_{\mathrm{tr}} \mathrm{G}^{\mathrm{o}}=\Delta_{\mathrm{tr}} \mathrm{H}^{\mathrm{o}}-\mathrm{T} \Delta_{\mathrm{tr}} \mathrm{S}^{\circ}$

where $\Delta_{\mathrm{tr}} \mathrm{G}^{\circ}$ and $\Delta_{\mathrm{tr}} \mathrm{H}^{\circ}$ are values already known.

\section{Fluorescence spectroscopy measurements}

The fluorescence emission spectra of $\mathrm{MB}$ in the investigated solutions were obtained using a Cary Eclipse Fluorescence Spectrophotometer (Agilent Technologies, USA). The slits selected were $5 \mathrm{~nm}$ for excitation and $5 \mathrm{~nm}$ for emission, and the spectra were acquired in the range of 630 to $850 \mathrm{~nm}$ at an excitation wavelength of $620 \mathrm{~nm}$. All spectra were collected at $25^{\circ} \mathrm{C}$ using $10 \mathrm{~mm}$ quartz cells.

\section{Results and Discussion}

\section{Dependence of the partition coefficient on the concentration} of methylene blue

It is well known that the solute partition coefficient $(\mathrm{K})$ is a thermodynamic parameter independent of solute concentration when a single chemical species is partitioned. However, if chemical processes that change the nature of the distributed solute begin to occur, the $\mathrm{K}$ will vary with the concentration of the transferred species. ${ }^{32}$

In solution, MB molecules can self-interact to form aggregates such as dimer, and even higher order aggregates..$^{33}$ Such molecular processes are influenced by several factors including concentration, $\mathrm{pH}$, temperature and solvent nature. ${ }^{34}$ In order to verify if only one MB chemical species is partitioning, the dependence of the MB partition coefficient on the concentration of the solute was determined. The $\mathrm{K}$ values were determined for the $\mathrm{MB}$ concentration ([MB]) range of 25 to $800 \mu \mathrm{mol} \mathrm{kg}{ }^{-1}$, in the $5^{\text {th }} \mathrm{TLL}$ of the PEO $1500+\mathrm{H}_{2} \mathrm{O}+\mathrm{Li}_{2} \mathrm{SO}_{4}$ ATPS at $25^{\circ} \mathrm{C}$, as shown in Figure 1.

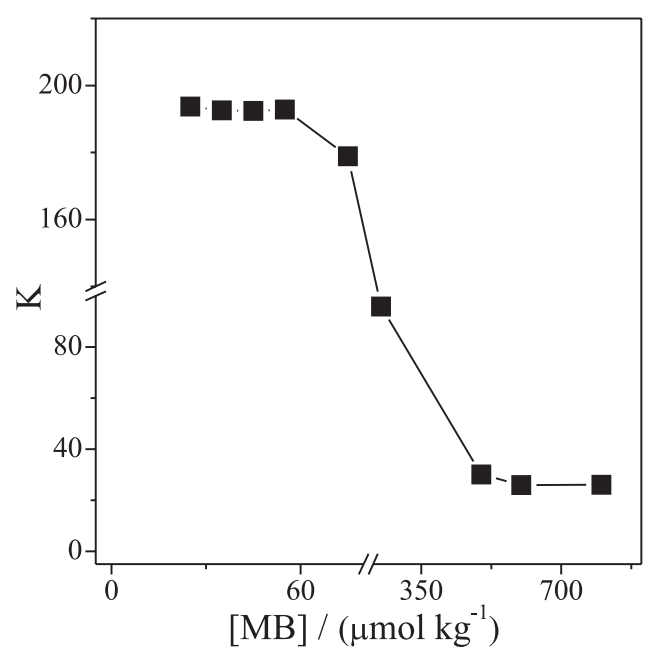

Figure 1. $\mathrm{MB} \mathrm{K}$ values as function of total dye concentration measured in the PEO $1500+\mathrm{H}_{2} \mathrm{O}+\mathrm{Li}_{2} \mathrm{SO}_{4}$ ATPS at $25^{\circ} \mathrm{C}$ and TLL $=51.67 \% \mathrm{~m} / \mathrm{m}$.

In the $25 \leq[\mathrm{MB}] \leq 55 \mu$ mol $\mathrm{kg}^{-1}$ range, the $\mathrm{K}$ values were constant, however, in the $55<[\mathrm{MB}] \leq 500 \mu \mathrm{mol} \mathrm{kg}{ }^{-1}$ interval, $\mathrm{K}$ values decreased monotonically, from 192 to 26 , while at $[\mathrm{MB}]>500 \mu \mathrm{mol} \mathrm{\textrm {kg } ^ { - 1 }}$ the $\mathrm{K}$ values became constant again. The first plateau, at a small MB concentration, indicates that the partitioning species was the MB monomers, while at a higher MB concentration (second plateau), MB dimers were distributed between both ATPS phases. In the transition region between monomers and dimers, there is a chemical equilibrium between $\mathrm{MB}$ species. ${ }^{35}$

From the fluorescence steady-state measurements of MB molecules we can describe the relative concentration of monomers and dimers present in both ATPS phases. This is possible, because the fluorescence emission of the monomers is self-quenched upon the formation of dimers or even larger aggregates in solution, as a transition from lowest excited singlet state to the ground state is forbidden for such multi-molecular species. ${ }^{36,37}$ The MB monomers in aqueous solution exhibit a fluorescence maximum at $684 \mathrm{~nm}$ with a quantum yield of 0.04 in water. ${ }^{38,39}$

To confirm the presence of monomers and/or dimers in all MB concentrations studied in partitioning experiments, fluorescence spectroscopy was applied to measure the MB emission intensity in top and bottom phases of the $5^{\text {th }}$ TLL of the PEO $1500+\mathrm{H}_{2} \mathrm{O}+\mathrm{Li}_{2} \mathrm{SO}_{4}$ ATPS at $25^{\circ} \mathrm{C}$. A better way to analyze the fluorescence data obtained is to plot $\mathrm{MB}$ maximum fluorescence as function of its concentration, as shown in Figure 2.

For both ATPS phases, when the MB concentration increased from 25 to $35 \mu \mathrm{mol} \mathrm{\textrm {kg } ^ { - 1 }}$ this led to the enhancement of the dye fluorescence intensity, from 350 to 550 (top phase) and 520 to 725 (bottom phase), which was caused by an increase in the content of MB monomers. 

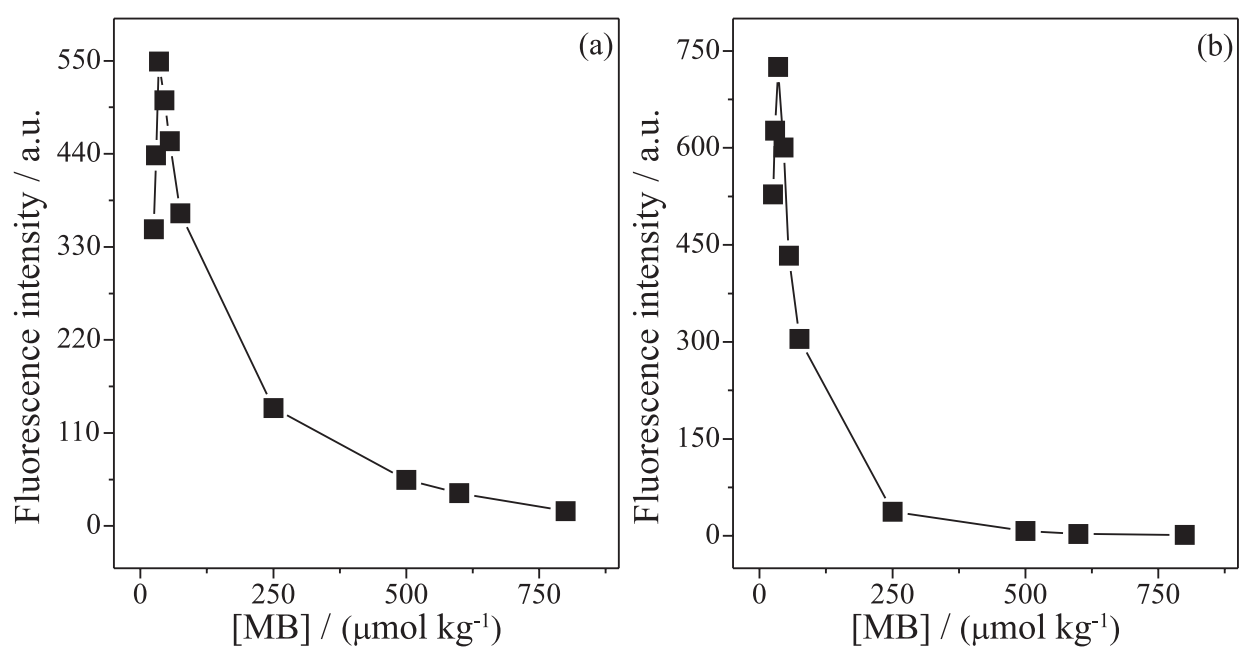

Figure 2. Maximum fluorescence intensity of MB as function of its concentration in (a) top and (b) bottom phase of the PEO $1500+\mathrm{H}_{2} \mathrm{O}+\mathrm{Li}_{2} \mathrm{SO}_{4} \mathrm{ATPS}$ at $25^{\circ} \mathrm{C}$ and TLL $=51.67 \% \mathrm{~m} / \mathrm{m}$. The error bars of each measurement was smaller than the size of the symbols used.

When $[\mathrm{MB}]>35 \mu \mathrm{mol} \mathrm{kg}{ }^{-1}$, the intensity of the emission band of the dye gradually decreased. This progressive quenching of fluorescence is in agreement with the model describing the equilibrium between monomers (fluorescent) and dye aggregates (non-fluorescent) in solution. ${ }^{37,40}$ Finally, at higher $\mathrm{MB}$ concentrations $\left([\mathrm{MB}] \geq 500 \mu \mathrm{mol} \mathrm{kg}{ }^{-1}\right)$, dye fluorescence almost disappeared, indicating that MB dimers predominate in both phases of an ATPS.

To ensure that only MB monomers were transferred between both ATPS phases, the total concentration of dye in the ATPS for all experiments carried out in this study was $35 \mu \mathrm{mol} \mathrm{kg} \mathrm{kg}^{-1}$.

Thermodynamic parameters of phenothiazine dye partition

To further understand the driving forces that determine the distribution behavior of phenothiazine dyes in different ATPSs and to understand the relationship between their structure and their $\mathrm{K}$ values, partition studies of four structurally similar dyes were performed. Figure 3 shows the $\mathrm{K}$ values of MB, AZB, AZA, and TA dyes versus TLL for the ATPS comprising of PEO $1500, \mathrm{MgSO}_{4}$ and $\mathrm{H}_{2} \mathrm{O}$ at $25^{\circ} \mathrm{C}$.

All $\mathrm{K}$ values were much higher than 1 showing that all phenothiazine compounds concentrated in the ATPS top phase, with values in the following order: $\mathrm{MB}>\mathrm{AZB}>$ AZA > TA. This shows that dye molecules with more methyl substituent have a large tendency to transfer from the bottom to the top phase in the ATPS. For all dyes studied, except for TA, the values of $\mathrm{K}$ increase almost exponentially as the TLL value grows.

Da Silva et al. ${ }^{41}$ studied the MB, AZA, and AZB partition behavior in an $n$-octanol/water biphasic system, and demonstrated that all the compounds exhibited,

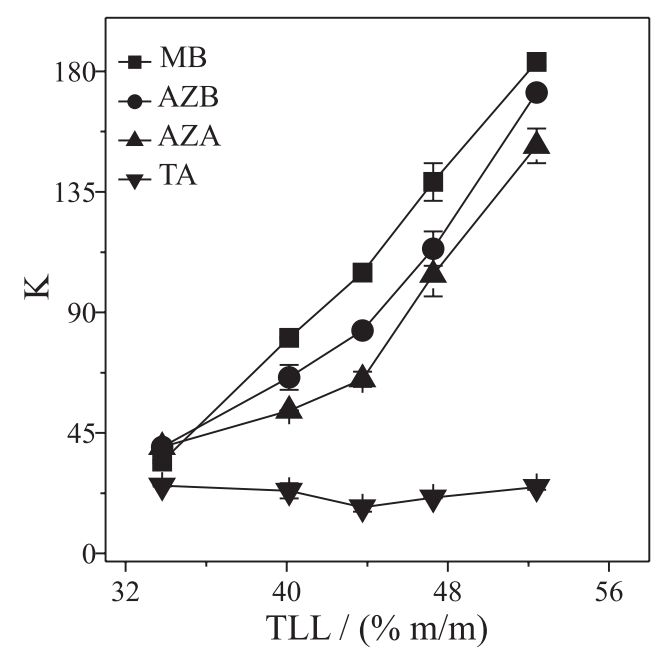

Figure 3. $\mathrm{K}$ values of phenothiazine dyes as a function of TLL in the PEO $1500+\mathrm{MgSO}_{4}+\mathrm{H}_{2} \mathrm{O}$ ATPS at $25^{\circ} \mathrm{C}$.

independent of their chemical structure, the same partitioning behavior between aqueous and organic phases. It was observed that the distribution coefficient $\left(D_{\text {oct/water }}\right)$ values were lower than $1\left(0.03 \leq D_{\text {oct/water }} \leq 0.42\right)$ when measured in acidic solution, and $\mathrm{D}_{\text {oct/water }}>1$ $\left(1.20 \leq \mathrm{D}_{\text {oct/water }} \leq 10.23\right)$ for values above $\mathrm{pH} 7.0$. It is clear from these results that ATPS are much more efficient at extracting phenothiazine from an aqueous solutions than water/octanol biphasic systems. As the partitioning coefficients of the phenothiazine dyes that were measured in all ATPSs investigated in our studies are larger than those obtained in octanol/water systems, which are biphasic systems with a higher (in relation to an ATPS) hydrophobic/ hydrophilic difference between both phases, we can therefore conclude that hydrophobic interaction is not the only driving force responsible for the phenothiazine dye distribution in an ATPS. 
In general, positive charged solutes are concentrated in ATPS bottom phases, ${ }^{42}$ and to the best of our knowledge, this work is the first investigation showing a cationic species (phenothiazine ring) being spontaneously transferred from the bottom to the top ATPS phase. For a better understanding of the molecular interactions that drive the partitioning of the dye in the PEO $1500+\mathrm{MgSO}_{4}+\mathrm{H}_{2} \mathrm{O}$ ATPS, a standard Gibbs free energy change of transfer, $\Delta_{\mathrm{tr}} \mathrm{G}^{\circ}$, was calculated using equation 3 . The $\Delta_{\mathrm{tr}} \mathrm{G}^{\circ}$ values for all dyes as a function of TLL for the ATPS comprising of PEO $1500, \mathrm{MgSO}_{4}$, and $\mathrm{H}_{2} \mathrm{O}$, at $25^{\circ} \mathrm{C}$, are presented in Figure 4 .

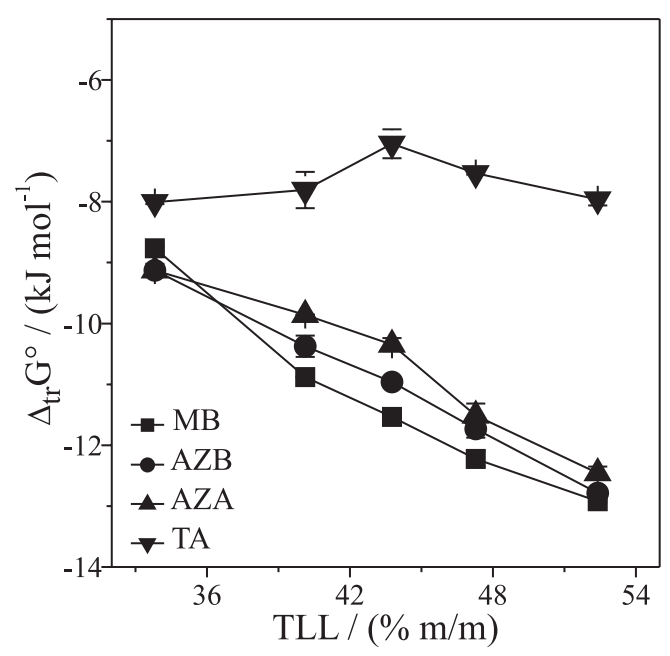

Figure 4. $\Delta_{\mathrm{tr}} \mathrm{G}^{\circ}$ values of phenothiazine dyes as a function of the TLL in the PEO $1500+\mathrm{MgSO}_{4}+\mathrm{H}_{2} \mathrm{O}$ ATPS at $25^{\circ} \mathrm{C}$.

Except for the TA molecules in which $\Delta_{\mathrm{tr}} \mathrm{G}^{\circ}$ values almost remained constant at around $-8.0 \mathrm{~kJ} \mathrm{~mol}^{-1}$, for all others dyes the $\Delta_{\mathrm{tr}} \mathrm{G}^{\circ}$ decreased almost linearly as TLL increased, with values ranging from -8.7 to $-12.9 \mathrm{~kJ} \mathrm{~mol}^{-1}$ for $\mathrm{MB},-9.1$ to $-12.7 \mathrm{~kJ} \mathrm{~mol}^{-1}$ for $\mathrm{AZB}$, and -9.1 to

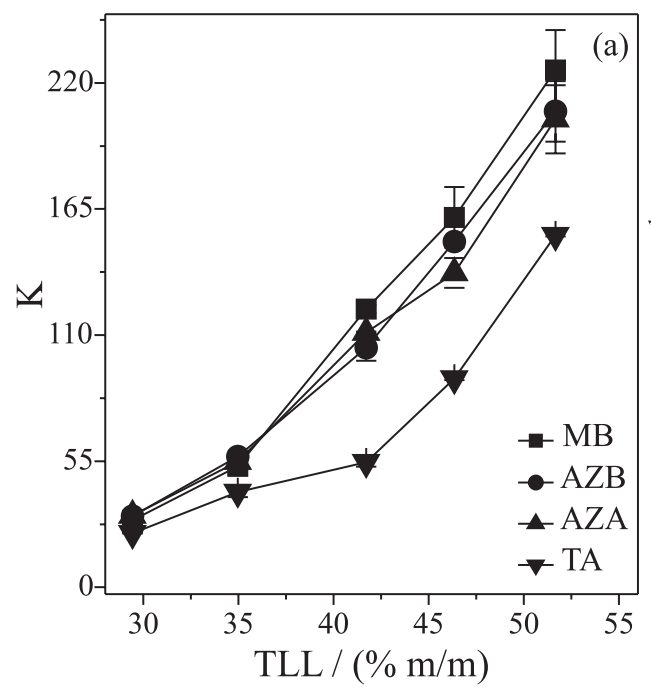

$-12.4 \mathrm{~kJ} \mathrm{~mol}^{-1}$ for AZA. The negative values of $\Delta_{\mathrm{tr}} \mathrm{G}^{\circ}$ indicate a preferential interaction of the dye molecules with the top phase components of the ATPS.

The partition behavior of the phenothiazine dyes was also evaluated in the system formed by PEO $1500+$ $\mathrm{Li}_{2} \mathrm{SO}_{4}+\mathrm{H}_{2} \mathrm{O}$, and the results are presented in Figure 5.

All dyes were concentrated in the top phase $(\mathrm{K}>1$, Figure $5 \mathrm{a}$ ) as shown by the negative $\Delta_{\mathrm{tr}} \mathrm{G}^{\circ}$ values that decreased almost linearly with an increase in the TLL (Figure 5b). It is worth noting that for TA in the PEO $1500+$ $\mathrm{Li}_{2} \mathrm{SO}_{4}+\mathrm{H}_{2} \mathrm{O}$ ATPS, the $\mathrm{K}$ values were not approximately constant as TLL increased, as was the case for PEO $1500+$ $\mathrm{MgSO}_{4}+\mathrm{H}_{2} \mathrm{O}$ ATPS. In the lithium ATPS, a methyl substitution on the amino group of dyes has a lower effect on the dyes' $\mathrm{K}$ values than when compared to the effect this has in the magnesium ATPS. To better understand the driving forces that governing the phenothiazine dye partition process, it is necessary to evaluate the factors that contribute to $\Delta_{\mathrm{tr}} \mathrm{G}^{\circ}$, namely, $\Delta_{\mathrm{tr}} \mathrm{H}^{\circ}$ and $\mathrm{T} \Delta_{\mathrm{tr}} \mathrm{S}^{\circ}$.

The enthalpic contribution of the molecular interactions to the transfer of dyes in an ATPS was measured using ITC. ITC is a very sensitive technique that can detect the very low energy fluxes (around $0.2 \mu \mathrm{W}$ ) that are associated with the different thermodynamic processes that occur with very small changes in a system enthalpy, such as in the dilution of solutes. ${ }^{43}$ As water is generally the main component in many different ATPSs, ${ }^{8}$ it is very important to understand the specific interaction that occurs between dyes and water molecules.

The excess partial molar enthalpy $\left(\mathrm{H}_{\mathrm{dye}}^{\mathrm{E}}\right)$ can provide a starting point for understanding the solute-solute, solutesolvent and solvent-solvent interactions. These excess enthalpies express the interaction asymmetry present in a real solution when compared with symmetrical

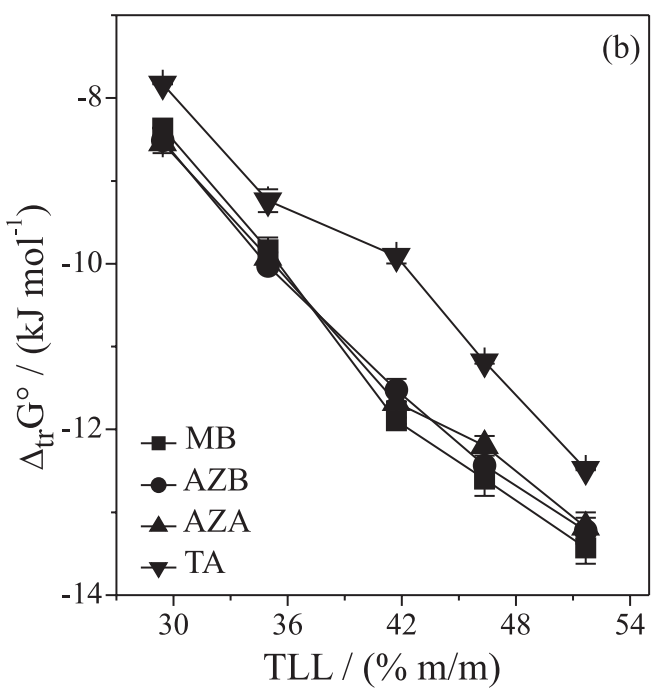

Figure 5. The (a) $\mathrm{K}$ and (b) $\Delta_{\mathrm{Ir}} \mathrm{G}^{\circ}$ values of phenothiazine dyes as a function of TLL in the PEO $1500+\mathrm{Li}_{2} \mathrm{SO}_{4}+\mathrm{H}_{2} \mathrm{O}$ ATPS at $25^{\circ} \mathrm{C}$. 
interactions $\left(\mathrm{E}_{\text {solute-solute }}=\mathrm{E}_{\text {solute-solvent }}=\mathrm{E}_{\text {solvent-solute }}\right)$ occurring in a hypothetical ideal solution. ${ }^{44}$ To compare the selfinteractions of different dyes (MB, AZB and AZA) as well as their interactions with water, the $\mathrm{H}_{\mathrm{dye}}^{\mathrm{E}}$ versus [dye] plots are shown in Figure 6.

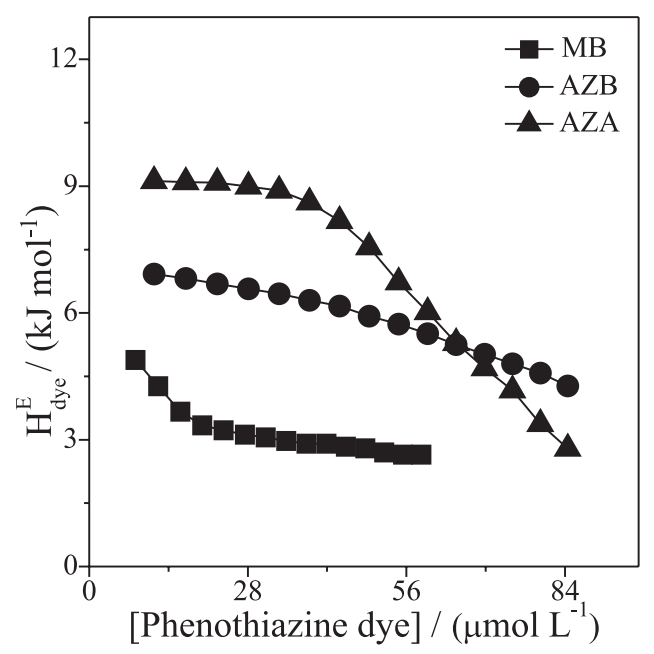

Figure 6. $\mathrm{H}_{\mathrm{dye}}^{\mathrm{E}}$ values of phenothiazine dyes as a function of the dye concentration measured in $\mathrm{H}_{2} \mathrm{O}$ at $25^{\circ} \mathrm{C}$.

Generally, the slope $\left(\partial \mathrm{H}_{\text {dye }}^{\mathrm{E}} / \partial[\right.$ dye $\left.]\right)$ of the $\mathrm{H}_{\mathrm{dye}}^{\mathrm{E}}$ versus [dye] curves expresses the contribution of the dye-dye interaction in solution toward the system enthalpy. In the [dye] range where $\partial \mathrm{H}_{\text {dye }}^{\mathrm{E}} / \partial[$ dye] is higher, dye-dye interaction is strong enough to lead to the formation of dye dimers, as was confirmed by fluorescence measurement (Figure S2, SI section).

In order to determine the dye-solvent interactions, the excess enthalpy of dyes for the infinite dilution condition $\left(\mathrm{H}_{\text {dye }}^{\mathrm{E}, \infty}\right)$ was calculated by extrapolating the $\mathrm{H}_{\text {dye }}^{\mathrm{E}} \times$ [dye] curves to zero dye concentration using an exponential

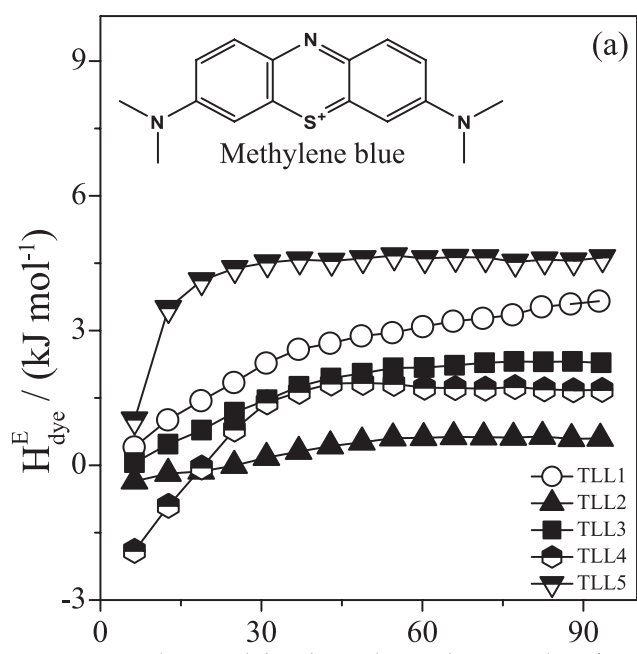

[Phenothiazine dye] / $\left(\mu \mathrm{mol} \mathrm{L}{ }^{-1}\right)$ fitting. The $\mathrm{H}_{\mathrm{dye}}^{\mathrm{E}, \infty}$ values of the dyes in water were: $7.3 \pm 0.4 \mathrm{~kJ} \mathrm{~mol}^{-1}$ for $\mathrm{MB}, 7.1 \pm 0.2 \mathrm{~kJ} \mathrm{~mol}^{-1}$ for AZB, and $9.2 \pm 0.6 \mathrm{~kJ} \mathrm{~mol}^{-1}$ for AZA. The difference in methyl group number on the phenothiazine fused rings does not significantly change the values of $\mathrm{H}_{\mathrm{dye}}^{\mathrm{E}, \infty}$, suggesting that water solvation mainly occurs around the planar rings of the dye. The process of dye-water mixing under infinite dilution conditions can be understood on the basis of water cavity formation and dye-water interactions. ${ }^{43}$ The $\mathrm{H}_{\text {dye }}^{\mathrm{E}, \infty}$ was endothermic, showing that the energy cost of breaking water-water interactions (cavity formation) is higher than the energy released during the dye solvation process.

To describe the energy involved in the interaction between dye molecules and ATPS phase components, the $\mathrm{H}_{\mathrm{dye}}^{\mathrm{E}}$ versus dye concentration data for phenothiazine dye compounds were obtained in ATPS top and bottom phases. Figure 7 shows the $\mathrm{H}_{\mathrm{dyc}}^{\mathrm{E}}$ values obtained by titration curves of the MB concentrate solution into the top phase (Figure 7a) or bottom phase (Figure 7b) for five TLLs of the PEO $1500+\mathrm{Li}_{2} \mathrm{SO}_{4}+\mathrm{H}_{2} \mathrm{O}$ ATPS at $25^{\circ} \mathrm{C}$. A similar plot was obtained for the AZB and AZA dyes (Figure S3, SI section).

For all TLL values, the increase in concentration of the dyes made the $\mathrm{H}_{\text {dye }}^{\mathrm{E}}$ values more positive in the top phase, while in the bottom phase, the enhancement of dye content made $\mathrm{H}_{\mathrm{dye}}^{\mathrm{E}}$ values less positive. This result shows that the dye-dye interaction is enthalpically unfavorable in the ATPS enriched polymer $\left(\partial \mathrm{H}_{\text {dye }}^{\mathrm{E}} / \partial[\right.$ dye $\left.]>0\right)$ and favorable in the ATPS salt rich phases $\left(\partial \mathrm{H}_{\text {dye }}^{\mathrm{E}} / \partial[\right.$ dye $\left.]<0\right)$.

To determine the energy of the interaction between the dye molecules and the ATPS components, the values of $\mathrm{H}_{\mathrm{dye}}^{\mathrm{E}, \infty}$ were obtained by extrapolation of $\mathrm{H}_{\mathrm{dye}}^{\mathrm{E}, \infty}$ versus [dye] curves to zero dye concentration. The $\mathrm{H}_{\mathrm{dye}}^{\mathrm{E}, \mathrm{o}}$ values of dyes $\mathrm{MB}, \mathrm{AZA}$, and AZB in the top and bottom phases for five

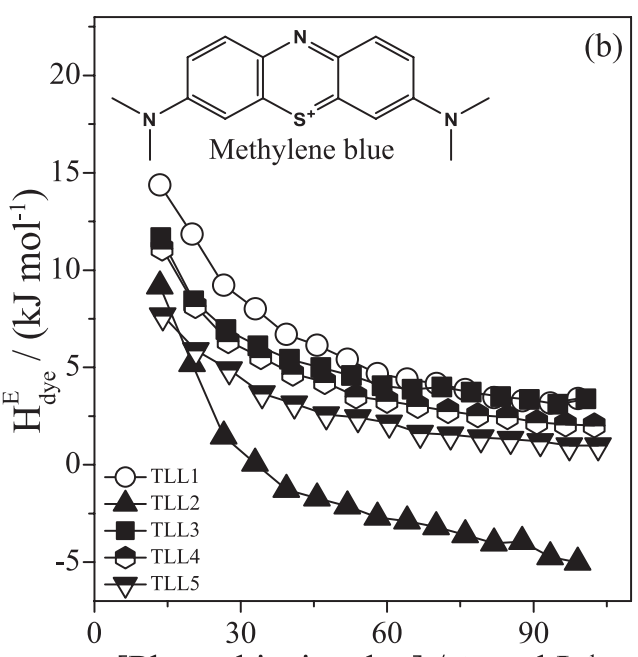

[Phenothiazine dye] / $(\mu \mathrm{mol} \mathrm{L}-1)$

Figure 7. $\mathrm{H}_{\text {dye }}^{\mathrm{E}}$ values for $\mathrm{MB}$ as function of the dye concentration in (a) top and (b) bottom phases of the PEO $1500+\mathrm{Li}_{2} \mathrm{SO}_{4}+\mathrm{H}_{2} \mathrm{O}$ ATPS at $25^{\circ} \mathrm{C}$. 
TLL of the PEO $1500+\mathrm{Li}_{2} \mathrm{SO}_{4}+\mathrm{H}_{2} \mathrm{O}$ ATPS are shown in Table 2.

The $\mathrm{H}_{\text {dye }}^{\mathrm{E}, \infty}$ values of phenothiazine dyes in the top phase were in general negative for all TLL, with the exception of AZB which presented positive values, but in low magnitude, for the first three TLL. The $\mathrm{H}_{\mathrm{dye}}^{\mathrm{E}, \infty}$ values in the top phase can be understood mainly as the net energy of the following processes: breaking of water-water, polymer-polymer and polymer-water interactions for cavity formation, and subsequent solvation of the dye molecule by the polymer and water. These negative $\mathrm{H}_{\mathrm{dye}}^{\mathrm{E}, \infty}$ values indicate that more energy is released in the solvation processes of the dyes than that absorbed in the cavity formation. However, in the bottom phase the dyes' $H_{\text {dye }}^{\mathrm{E}, \infty}$ values were endothermic for all TLL, showing that the energy cost of disrupting of salt-salt, water-water, and water-salt interactions, is much higher than the energy released from dye-salt and dye-water interactions.

In order to directly determine energy of the dye-PEO $\left(\mathrm{E}_{\text {dye-EO }}\right)$ and dye-salt $\left(\mathrm{E}_{\text {dye-salt }}\right)$ interactions, the $\mathrm{H}_{\mathrm{dye}}^{\mathrm{E}, \infty}$ values obtained in water were subtracted from the $\mathrm{H}_{\mathrm{dye}}^{\mathrm{E}, \infty}$ values in the top and bottom phases of the ATPS, respectively, as determined by equations 7 and 8 :

$\mathrm{E}_{\text {dye-EO }}=\mathrm{H}_{\text {dye-TP }}^{\mathrm{E}, \infty}-\mathrm{H}_{\text {dye- } \mathrm{H}_{2} \mathrm{O}}^{\mathrm{E}, \infty}$
$\mathrm{E}_{\text {dye-salt }}=\mathrm{H}_{\text {dye-BP }}^{\mathrm{E}, \infty}-\mathrm{H}_{\text {dye- } \mathrm{H}_{2} \mathrm{O}}^{\mathrm{E}, \infty}$

where $\mathrm{H}_{\mathrm{dye}-\mathrm{TP}}^{\mathrm{E}, \infty}$ and $\mathrm{H}_{\mathrm{dye}-\mathrm{BP}}^{\mathrm{E}, \infty}$ are the excess partial molar enthalpy of dyes at infinite dilution in the top and bottom phases, respectively, measured in the PEO $1500+\mathrm{Li}_{2} \mathrm{SO}_{4}+$ $\mathrm{H}_{2} \mathrm{O}$ ATPS, and $\mathrm{H}_{\text {dye- } \mathrm{H}_{2} \mathrm{O}}^{\mathrm{E}, \infty}$ is the same parameter for solutes dissolved in pure water.

As showed in Table 2, the $\mathrm{E}_{\text {dye-EO }}$ values were negative for all dyes indicating an enthalpically favorable specific dye-EO interaction. In general, with an increase in TLL, the $\mathrm{E}_{\text {dye-EO }}$ values were almost constant, however, $\mathrm{E}_{\text {dye-salt }}$ values were positive and increased with an increase in the TLL, with the exception of AZB in which values varied little, demonstrating that the dye-salt interaction is repulsive. This enthalpically unfavorable interaction is probably due to an electrostatic repulsion between the salt cation and condensed ring cation of the dye and/or caused by the hydrophobic nature of the dye which makes it less soluble in an enriched salt phase. The $\mathrm{E}_{\text {dye-EO }}$ and $\mathrm{E}_{\text {dye-salt }}$ values show that dye concentration in the ATPS top phase occurs due to an attractive interaction between the dye and the PEO, and a repulsive interaction between the dye and the electrolytes. Despite the structural differences between the phenothiazine dyes, $\mathrm{E}_{\mathrm{dye}-\mathrm{EO}}$ and $\mathrm{E}_{\mathrm{dye}-\text { salt }}$ were similar for all solutes, showing that the interactions occur through the dye condensed ring.

Table 2. $\mathrm{H}_{\text {dye }}^{\mathrm{E}, \infty}$ values of MB, AZB, and AZA in top (TP) and bottom (BP) phases, and $\mathrm{E}_{\text {dye-EO }}$ and $\mathrm{E}_{\text {dye-salt }}$ for five TLL of the PEO $1500+\mathrm{Li}_{2} \mathrm{SO}_{4}+\mathrm{H}_{2} \mathrm{O}$ ATPS at $25^{\circ} \mathrm{C}$

\begin{tabular}{|c|c|c|c|c|}
\hline $\operatorname{TLL} /(\% \mathrm{~m} / \mathrm{m})$ & $\mathrm{H}_{\mathrm{dye}}^{\mathrm{E}, \infty}(\mathrm{TP}) /\left(\mathrm{kJ} \mathrm{mol}^{-1}\right)$ & $\mathrm{E}_{\mathrm{dye}-\mathrm{EO}} /\left(\mathrm{kJ} \mathrm{mol}^{-1}\right)$ & $\mathrm{H}_{\mathrm{dye}}^{\mathrm{E}, \infty}(\mathrm{BP}) /\left(\mathrm{kJ} \mathrm{mol}^{-1}\right)$ & $\mathrm{E}_{\text {dye-salt }} /\left(\mathrm{kJ} \mathrm{mol}^{-1}\right)$ \\
\hline \multicolumn{5}{|c|}{$\mathrm{PEO} 1500+\mathrm{Li}_{2} \mathrm{SO}_{4}+\mathrm{H}_{2} \mathrm{O}(\mathrm{MB})$} \\
\hline 29.43 & $-0.30 \pm 0.01$ & $-7.6 \pm 0.4$ & $23 \pm 1$ & $16 \pm 1$ \\
\hline 34.97 & $-0.50 \pm 0.01$ & $-7.8 \pm 0.4$ & $25 \pm 1$ & $18 \pm 1$ \\
\hline 41.71 & $-0.74 \pm 0.01$ & $-8.0 \pm 0.4$ & $28 \pm 1$ & $21 \pm 1$ \\
\hline 46.36 & $-3.33 \pm 0.01$ & $-10.6 \pm 0.4$ & $34 \pm 3$ & $27 \pm 3$ \\
\hline 51.67 & $-1.39 \pm 0.01$ & $-8.7 \pm 0.4$ & $40 \pm 2$ & $33 \pm 2$ \\
\hline \multicolumn{5}{|c|}{ PEO $1500+\mathrm{Li}_{2} \mathrm{SO}_{4}+\mathrm{H}_{2} \mathrm{O}(\mathrm{AZB})$} \\
\hline 29.43 & $0.14 \pm 0.01$ & $-7.0 \pm 0.2$ & $29 \pm 1$ & $22 \pm 1$ \\
\hline 34.97 & $0.84 \pm 0.07$ & $-6.3 \pm 0.2$ & $29 \pm 2$ & $22 \pm 2$ \\
\hline 41.71 & $0.44 \pm 0.01$ & $-6.7 \pm 0.2$ & $28.6 \pm 0.4$ & $21.5 \pm 0.5$ \\
\hline 46.36 & $-1.74 \pm 0.04$ & $-8.8 \pm 0.2$ & $27 \pm 2$ & $20 \pm 2$ \\
\hline 51.67 & $-3.1 \pm 0.3$ & $-10.2 \pm 0.2$ & $28 \pm 2$ & $21 \pm 2$ \\
\hline \multicolumn{5}{|c|}{ PEO $1500+\mathrm{Li}_{2} \mathrm{SO}_{4}+\mathrm{H}_{2} \mathrm{O}(\mathrm{AZA})$} \\
\hline 29.43 & $-1.77 \pm 0.01$ & $-11.0 \pm 0.6$ & $31 \pm 1$ & $22 \pm 1$ \\
\hline 34.97 & $-0.04 \pm 0.01$ & $-9.2 \pm 0.6$ & $31 \pm 2$ & $22 \pm 2$ \\
\hline 41.71 & $-3.32 \pm 0.01$ & $-12.5 \pm 0.6$ & $32 \pm 1$ & $23 \pm 1$ \\
\hline 46.36 & $-3.1 \pm 0.3$ & $-12.3 \pm 0.7$ & $37 \pm 2$ & $28 \pm 2$ \\
\hline 51.67 & $-8.6 \pm 0.6$ & $-17.8 \pm 0.9$ & $43 \pm 3$ & $34 \pm 3$ \\
\hline
\end{tabular}

Experimental measure of thionin acetate (TA) was not possible due to precipitation. TLL: tie line length; $\mathrm{H}_{\mathrm{dye}}^{\mathrm{E}, \infty}$ : excess enthalpy of dye at infinite dilution conditions; TP: top phase; E: energy of interaction; BP: bottom phase; PEO: poly(ethylene oxide); MB: methylene blue; AZB: azure B; AZA: azure A. 
By using the $\mathrm{H}_{\mathrm{dye}}^{\mathrm{E}, \infty}$ measured in both ATPS phases it is possible to calculate the standard enthalpy change of transfer $\left(\Delta_{\mathrm{tI}} \mathrm{H}^{\circ}\right)$ for the solute using equation 5. The $\Delta_{\mathrm{tr}} \mathrm{H}^{\circ}$ parameter expresses the enthalpy change of the system when one mole of dye at infinitely diluted conditions is transferred from the bottom phase to the top phase of an ATPS. With this thermodynamic condition (infinite dilution), we can assume that the solute partitioning will not alter the composition of the equilibrium phases. In this way, the enthalpy change is related only to the interaction changes occurring during the transfer process of the solute. Figure 8 shows $\Delta_{\mathrm{tr}} \mathrm{H}^{\circ}$ as a function of TLL for the PEO $1500+\mathrm{Li}_{2} \mathrm{SO}_{4}+\mathrm{H}_{2} \mathrm{O}$ ATPS at $25^{\circ} \mathrm{C}$.

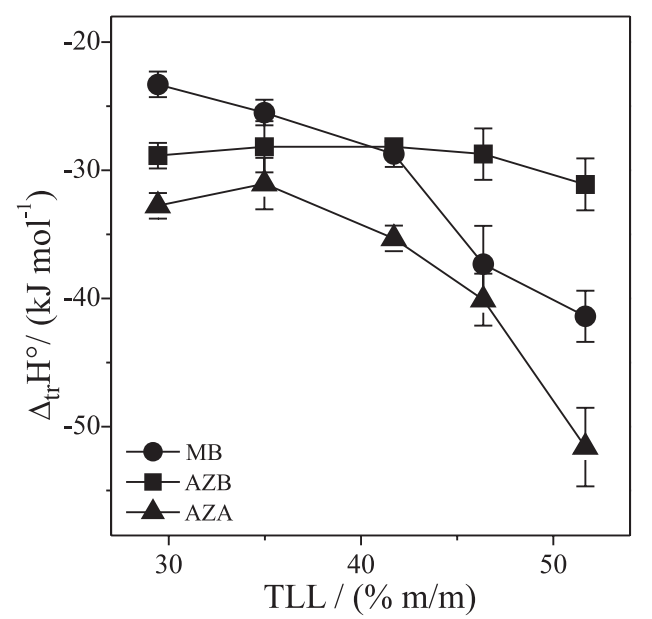

Figure 8. $\Delta_{\mathrm{tr}} \mathrm{H}^{\circ}$ values of phenothiazine dyes as a function of TLL for the PEO $1500+\mathrm{Li}_{2} \mathrm{SO}_{4}+\mathrm{H}_{2} \mathrm{O}$ ATPS at $25^{\circ} \mathrm{C}$.

For all TLL values, the dye transference processes are exothermic and as the TLL increases, the $\Delta_{\mathrm{tr}} \mathrm{H}^{\circ}$ becomes more negative, ranging in values from $-23.1 \pm 0.6$ to $-51 \pm 1 \mathrm{~kJ} \mathrm{~mol}^{-1}$, showing that as the ATPS phases became more concentrated (salt in bottom phase and polymer in top phase), the interactions in the salt and polymer enriched phases became more repulsive and attractive, respectively.

To the best of our knowledge, these results are the first enthalpic measurements of the transfer process of phenothiazine dyes in an ATPS. However, the transfer thermodynamics of many other solutes in different ATPSs have been studied using different approach. ${ }^{14,45,46}$ Mageste et al. ${ }^{14}$ used microcalorimetry to determine the $\Delta_{\mathrm{tr}} \mathrm{H}^{\circ}$ of the natural dye norbixin in different ATPSs formed by various mixtures of aqueous solutions of PEO or L35 triblock copolymer and a sodium tartrate or succinate salt, and they reported values ranging from $-2.7 \pm 0.3$ to $-9.1 \pm 0.5 \mathrm{~kJ} \mathrm{~mol}^{-1}$. Norbixin $\Delta_{\mathrm{tr}} \mathrm{H}^{\circ}$ values were less negative than those for the phenothiazine dyes, showing that the presence of an aromatic ring increases dye-PEO and dye-salt interaction.
Using the classical thermodynamic relation (equation 6), it is possible to calculate $\mathrm{T} \Delta_{\mathrm{tr}} \mathrm{S}^{\circ}$. The $\mathrm{T} \Delta_{\mathrm{tr}} \mathrm{S}^{\circ}$ term is related to an increase or decrease in the number of different possibilities for distributing the components present in the system, which occurs due to the transfer of dye molecules from the bottom phase to the top phase. The $\mathrm{T} \Delta_{\mathrm{tr}} \mathrm{S}^{\circ}$ values for $\mathrm{MB}, \mathrm{AZB}$, and $\mathrm{AZA}$ as a function of TLL for the PEO $1500+\mathrm{Li}_{2} \mathrm{SO}_{4}+\mathrm{H}_{2} \mathrm{O}$ ATPS, at $25^{\circ} \mathrm{C}$, are presented in Figure 9.

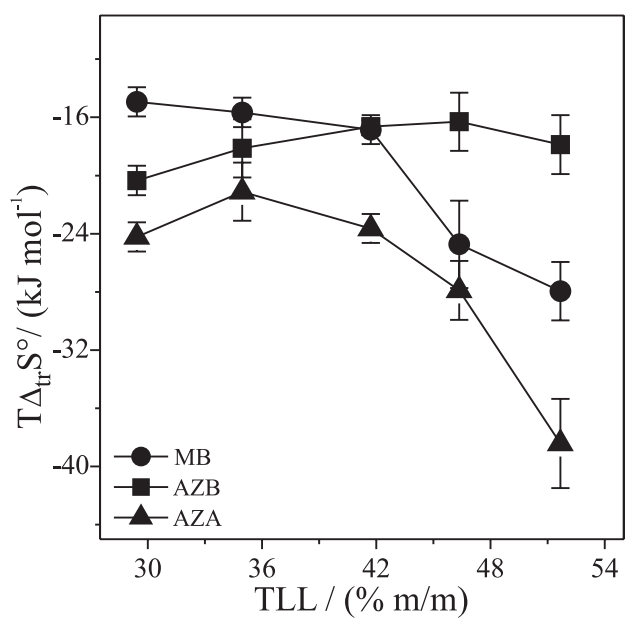

Figure 9. The $\mathrm{T} \Delta_{\mathrm{tr}} \mathrm{S}^{\circ}$ of phenothiazine dyes as a function of TLL for the PEO $1500+\mathrm{Li}_{2} \mathrm{SO}_{4}+\mathrm{H}_{2} \mathrm{O}$ ATPS at $25^{\circ} \mathrm{C}$.

The transfer of phenothiazine dyes from the bottom phase to the top phase occurs at $\mathrm{T} \Delta_{\mathrm{tr}} \mathrm{S}^{\circ}<0$ for all TLL values, showing that the processes were directed by enthalpic contributions. This decrease in the entropy of the system could be attributed to a low number of molecular configurations present in the ATPS top phase as compared to the number of possible molecular distributions in ATPS bottom phase, which is mainly due to a low number of water molecules being present in the polymer enriched phase. ${ }^{47}$ The $\mathrm{T} \Delta_{\mathrm{tr}} \mathrm{S}^{\circ}$ values became more negative as TLL increased because the difference in the water content between bottom and top phases increased as the TLL values became larger. ${ }^{30}$ Despite the fact that a decrease in the system entropy occurs for the transfer of many solutes in different ATPSs, ${ }^{14,22,46}$ this $\mathrm{T} \Delta_{\mathrm{tr}} \mathrm{S}^{\circ}$ decrease is not the only trend that is observed. Alcântara et al. ${ }^{23}$ reported papers on $\alpha$-lactalbumin $(\alpha-\mathrm{la})$ and $\beta$-lactoglobulin ( $\beta$-lg) partitioning in an ATPS containing PEO and sodium polyacrylate. The thermodynamic analysis of this work indicated that the partitioning of $\alpha$-la was accompanied by endothermic heat and was entropically driven, while $\beta$-lg partitioning was accompanied by exothermic heat and was enthalpically driven at low polymer concentrations and entropically driven at high polymer concentrations. 


\section{Cation effect on phenothiazine dye partition behavior}

As generally occurs with other solute partitioning in ATPSs, ${ }^{8,14,15}$ the $\mathrm{K}$ values of phenothiazine dyes and the dependence of these values on the TLL could be affected by the nature of the ATPS electrolyte. Cation effects are strong on the partitioning behavior of different solutes between ATPS phases and follow the order $\mathrm{Li}^{+}>\mathrm{Na}^{+}>\mathrm{Mg}^{+2}{ }^{2,15}{ }^{8}$ The cation effect is explained by some authors ${ }^{46,48,49}$ as being due to the existence of a PEO chain that is absorbed by ATPS cation forming a pseudopolycation which interacts attractively (mainly electrostatically) with anion species. The presence of the pseudopolycation in the top ATPS phase should give rise to repulsive forces against the phenothiazine dye (cationic condensed ring) in that phase. Probably in the bottom phase to the top phase should be attributed to specific interactions (dipole-dipole, charge transfer, and hydrophobic) between dye molecules and the PEO chain, which in magnitude exceed the dyepseudopolycation electrostatic repulsive interaction.

Figure 10 shows the $\mathrm{K}$ values of phenothiazine dyes plotted as a function of TLL for an ATPS comprising
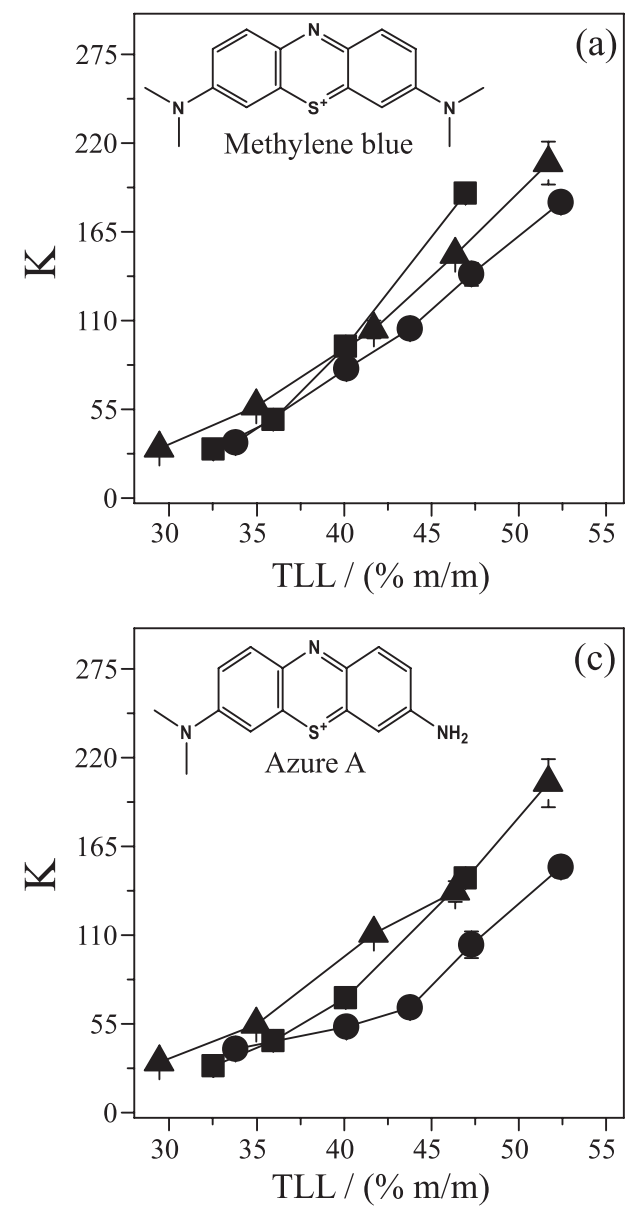

of PEO $1500+\mathrm{H}_{2} \mathrm{O}$ and different sulfate salts $\left(\mathrm{MgSO}_{4}\right.$, $\mathrm{Na}_{2} \mathrm{SO}_{4}$ and $\mathrm{Li}_{2} \mathrm{SO}_{4}$ ) at $25^{\circ} \mathrm{C}$.

The $\mathrm{K}$ values were little affected by the change in the cation nature suggesting that dye-pseudopolycation repulsive electrostatic interaction has only a small effect on the molecular interactions that drive the partitioning of these dyes. Despite this small cation effect, it is interesting to observe that the lower the number of methylene groups in the chemical structure of a dye, the lower the cation effect on the partitioning behavior of the dye. The cation effect dependence on the chemical structure of the phenothiazine could be caused by the electronic inductive effect attributed to the $-\mathrm{CH}_{3}$ group. According to this model, the $-\mathrm{CH}_{3}$ group should increase the electron flux through the phenol condensed ring, thus decreasing the net positive charge around the sulfur atom. The positive charge on the phenothiazine dye molecules ${ }^{41}$ and the intensity of the dye-pseudopolycation electrostatic repulsion should follow the order: $\mathrm{MB}<\mathrm{AZB}<\mathrm{AZA}$ $<$ TA, which is exactly the same order as that observed in the cation effect, on the $\mathrm{K}$ values dependence on dye chemical structure. This cation effect on the dye $\mathrm{K}$ values
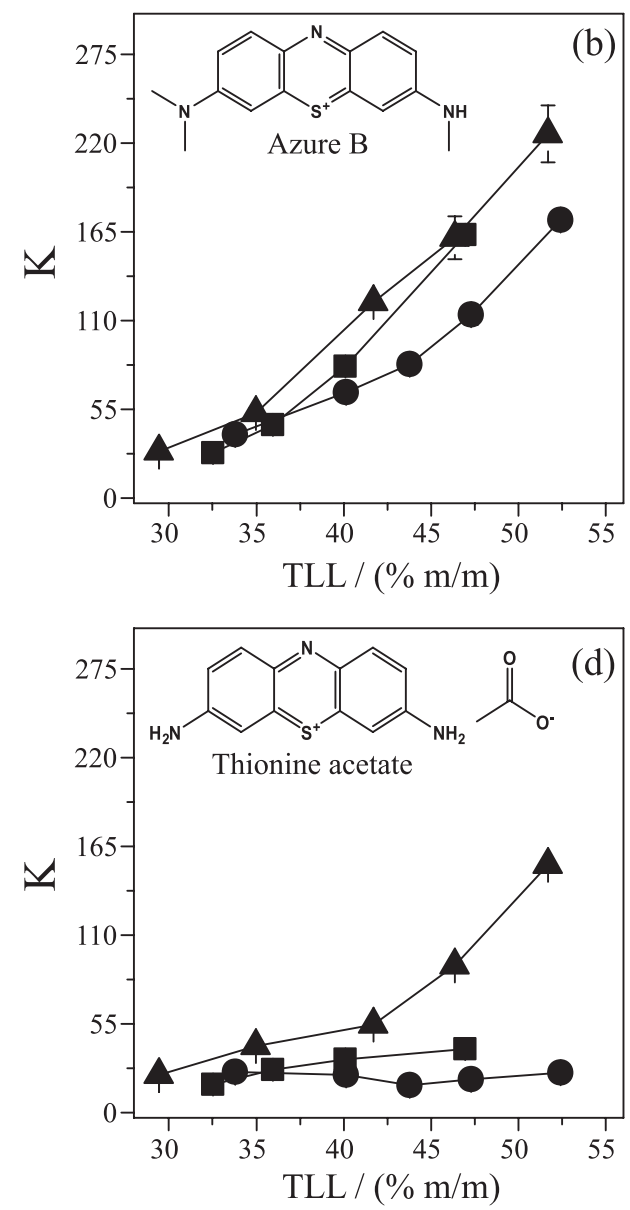

Figure 10. Cation effect on $\mathrm{K}$ values for the (a) MB; (b) AZB; (c) AZA; and (d) TA partition in the PEO $1500+\mathrm{MgSO}_{4}+\mathrm{H}_{2} \mathrm{O}(\bullet) ; \mathrm{PEO}^{1500}+\mathrm{Na}_{2} \mathrm{SO}_{4}+$ $\mathrm{H}_{2} \mathrm{O}(\boldsymbol{\square})$; and PEO $1500+\mathrm{Li}_{2} \mathrm{SO}_{4}+\mathrm{H}_{2} \mathrm{O}(\boldsymbol{\Delta})$ ATPSs at $25{ }^{\circ} \mathrm{C}$. 
can be evaluated in terms of thermodynamic parameters, as presented in Table 3 .

Table 3. Phenothiazine dye transfer thermodynamic parameters obtained for PEO $1500+\mathrm{MgSO}_{4}+\mathrm{H}_{2} \mathrm{O}(\mathrm{TLL}=40.12 \% \mathrm{~m} / \mathrm{m})$, PEO $1500+$ $\mathrm{Na}_{2} \mathrm{SO}_{4}+\mathrm{H}_{2} \mathrm{O}(\mathrm{TLL}=40.10 \% \mathrm{~m} / \mathrm{m})$, PEO $1500+\mathrm{Li}_{2} \mathrm{SO}_{4}+\mathrm{H}_{2} \mathrm{O}$ (TLL $=41.71 \% \mathrm{~m} / \mathrm{m}$ ) ATPSs at $25^{\circ} \mathrm{C}$

\begin{tabular}{|c|c|c|c|}
\hline & $\mathrm{Li}^{+}$ & $\mathrm{Na}^{+}$ & $\mathrm{Mg}^{2+}$ \\
\hline \multicolumn{4}{|c|}{ MB } \\
\hline$\Delta_{\mathrm{tr}} \mathrm{G}^{\circ} /\left(\mathrm{kJ} \mathrm{mol}^{-1}\right)$ & $-11.90 \pm 0.04$ & $-11.26 \pm 0.04$ & $-10.88 \pm 0.01$ \\
\hline$\Delta_{\mathrm{tr}} \mathrm{H}^{\circ} /\left(\mathrm{kJ} \mathrm{mol}^{-1}\right)$ & $-29 \pm 1$ & $-25 \pm 1$ & $-32 \pm 1$ \\
\hline $\mathrm{T} \Delta_{\mathrm{tr}} \mathrm{S}^{\circ} /\left(\mathrm{kJ} \mathrm{mol}^{-1}\right)$ & $-17 \pm 1$ & $-14 \pm 1$ & $-21 \pm 1$ \\
\hline \multicolumn{4}{|c|}{ AZB } \\
\hline$\Delta_{\mathrm{tr}} \mathrm{G}^{\circ} /\left(\mathrm{kJ} \mathrm{mol}^{-1}\right)$ & $-11.5 \pm 0.1$ & $-10.91 \pm 0.09$ & $-10.9 \pm 0.2$ \\
\hline$\Delta_{\mathrm{tr}} \mathrm{H}^{\circ} /\left(\mathrm{kJ} \mathrm{mol}^{-1}\right)$ & $-28.2 \pm 0.4$ & $-35 \pm 1$ & $-34 \pm 1$ \\
\hline $\mathrm{T} \Delta_{\mathrm{tr}} \mathrm{S}^{\circ} /\left(\mathrm{kJ} \mathrm{mol}^{-1}\right)$ & $-17 \pm 1$ & $-24 \pm 1$ & $-23 \pm 1$ \\
\hline \multicolumn{4}{|c|}{$\mathrm{AZA}$} \\
\hline$\Delta_{\mathrm{tr}} \mathrm{G}^{\circ} /\left(\mathrm{kJ} \mathrm{mol}^{-1}\right)$ & $-11.68 \pm 0.01$ & $-10.6 \pm 0.1$ & $-9.86 \pm 0.01$ \\
\hline$\Delta_{\mathrm{tr}} \mathrm{H}^{\circ} /\left(\mathrm{kJ} \mathrm{mol}^{-1}\right)$ & $-35 \pm 1$ & $-35 \pm 1$ & $-31 \pm 2$ \\
\hline $\mathrm{T} \Delta_{\mathrm{tr}} \mathrm{S}^{\circ} /\left(\mathrm{kJ} \mathrm{mol}^{-1}\right)$ & $-24 \pm 1$ & $-24 \pm 1$ & $-21 \pm 2$ \\
\hline \multicolumn{4}{|c|}{$\mathrm{TA}$} \\
\hline$\Delta_{\mathrm{tr}} \mathrm{G}^{\circ} /\left(\mathrm{kJ} \mathrm{mol}^{-1}\right)$ & $-9.91 \pm 0.09$ & $-8.7 \pm 0.2$ & $-7.8 \pm 0.3$ \\
\hline$\Delta_{\mathrm{tr}} \mathrm{H}^{\circ} /\left(\mathrm{kJ} \mathrm{mol}^{-1}\right)$ & - & - & - \\
\hline $\mathrm{T} \Delta_{\mathrm{tr}} \mathrm{S}^{\circ} /\left(\mathrm{kJ} \mathrm{mol}^{-1}\right)$ & - & - & - \\
\hline
\end{tabular}

Experimental measure of TA was not possible due to precipitation. MB: methylene blue; $\Delta_{\mathrm{tr}} \mathrm{G}^{\circ}$ : dye transfer standard Gibbs free energy change; $\Delta_{\mathrm{tr}} \mathrm{H}^{\circ}$ : dye transfer standard enthalpy change; $\Delta_{\mathrm{tr}} \mathrm{S}^{\circ}$ : dye transfer standard entropy change; AZB: azure B; AZA: azure A; TA: thionin acetate.

The $\Delta_{\mathrm{tr}} \mathrm{G}^{\circ}, \Delta_{\mathrm{tr}} \mathrm{H}^{\circ}$ and $\mathrm{T} \Delta_{\mathrm{tr}} \mathrm{S}^{\circ}$ values are negative, showing that for all ATPS dyes the transfer process is enthalpically driven. The transfer process of phenothiazine dyes from the bottom phase (higher entropy) to the top phase (lower entropy) lead to negative $\mathrm{T} \Delta_{\mathrm{tr}} \mathrm{S}^{\mathrm{o}}$ values that are compensated by the exothermic process $\left(\Delta_{\mathrm{tr}} \mathrm{H}^{\circ}<0\right)$ of the interaction between the dyes and the top phase components.

In addition, cation effect is not observable in the $\Delta_{\mathrm{tr}} \mathrm{G}^{\circ}$ parameter, but it is quite pronounced in $\Delta_{\mathrm{tt}} \mathrm{H}^{\circ}$ and $\mathrm{T} \Delta_{\mathrm{tr}} \mathrm{S}^{\circ}$. It is therefore clear that the cation effect is an enthalpic-entropic compensated process, ${ }^{47}$ i.e., a change $\Delta_{\mathrm{tr}} \mathrm{H}^{\circ}$ is neutralized by a modification in $\mathrm{T} \Delta_{\mathrm{tr}} \mathrm{S}^{\mathrm{o}}$, that occurs in order to keep $\Delta_{\mathrm{tr}} \mathrm{G}^{\circ}$ almost constant.

\section{Anion effect on the partition behavior phenothiazine dyes}

To determine the relative cation/anion contributions to the phenothiazine dye transfer process in ATPSs, we also evaluated the anion effect on the thermodynamic parameters associated with the phenothiazine dye partition process. The effect of an anion on the partition of MB, AZA, and AZB in ATPSs formed by PEO 1500 and sodium salts are shown in Figure 11. The TA partitioning experiment in PEO $1500+\mathrm{Na}_{2} \mathrm{C}_{4} \mathrm{H}_{4} \mathrm{O}_{6}+\mathrm{H}_{2} \mathrm{O}, \mathrm{PEO} 1500+\mathrm{Na}_{3} \mathrm{C}_{6} \mathrm{H}_{5} \mathrm{O}_{7}+$ $\mathrm{H}_{2} \mathrm{O}$, and PEO $1500+\mathrm{Na}_{2} \mathrm{SO}_{4}+\mathrm{H}_{2} \mathrm{O}$ ATPSs was not possible due to the dye decomposition process.

Contrary to the cation effect, the nature of the anion influences the $\mathrm{K}$ values of phenothiazine dyes the following order: $\mathrm{K}\left(\mathrm{SO}_{4}{ }^{2-}\right)>\mathrm{K}\left(\mathrm{C}_{4} \mathrm{H}_{4} \mathrm{O}_{6}{ }^{2-}\right)>\mathrm{K}\left(\mathrm{C}_{6} \mathrm{H}_{5} \mathrm{O}_{7}{ }^{3-}\right)$. This strong sulfate effect in the partition behavior of phenothiazine dyes, compared to the cases of the other two organic anions, may be explained because higher charge density of the $\mathrm{SO}_{4}{ }^{2-}$ anion compared to those of the tartrate and citrate ions, which causes a more repulsive dye-salt interaction in the bottom phase that favors the transfer of dyes to the top phase. These results can be evaluated in terms of the $\Delta_{\mathrm{tr}} \mathrm{G}^{\circ}$, $\Delta_{\mathrm{tr}} \mathrm{H}^{\circ}$, and $\mathrm{T} \Delta_{\mathrm{tr}} \mathrm{S}^{\circ}$ thermodynamic parameters, according to Table 4.

All transfer thermodynamic parameters were negative following the order: $\mathrm{SO}_{4}{ }^{2-}<\mathrm{C}_{4} \mathrm{H}_{4} \mathrm{O}_{6}{ }^{2-}<\mathrm{C}_{6} \mathrm{H}_{5} \mathrm{O}_{7}{ }^{3-}$ indicating that the intensity of dye-salt repulsion should follow the inverse order, i.e., $\mathrm{C}_{6} \mathrm{H}_{5} \mathrm{O}_{7}{ }^{3-}<\mathrm{C}_{4} \mathrm{H}_{4} \mathrm{O}_{6}{ }^{2-}<\mathrm{SO}_{4}{ }^{2-}$.

\section{Conclusions}

The use of MB, AZB, AZA, and TA as probes for studying the driving forces behind the process of cationic dye transfer in different ATPSs was presented in this work for the first time. The transfer process of phenothiazine dyes from the bottom to the top phase was exothermic and occurred with an accompanying reduction in system entropy. Attractive dye-PEO and repulsive dyeelectrolyte interactions contributed to the decrease in enthalpy, while negative values for $\mathrm{T} \Delta_{\mathrm{tr}} S^{\circ}$ were attributed to the transfer of the dyes from higher (bottom phase) to lower (top phase) configurational entropy regions. Despite the repulsive interaction between the cationic dye and the pseudopolycation formed in the top phase, attractive interactions (dipole-dipole, charge transfer, and hydrophobic) between the solute and the PEO chain outweighed the electrostatic repulsion. Interestingly, the difference in dye chemical structure had little effect on the dye-EO and dye-salt enthalpic interaction energy, showing that this interaction is mainly promoted by the dye condensed ring. These results provide fundamental knowledge for comprehending the partitioning of different solutes in ATPS. In addition, this study can be useful for the practical application of ATPS, which are environmentally safe methods, in the extraction and purification of these drug candidates. 

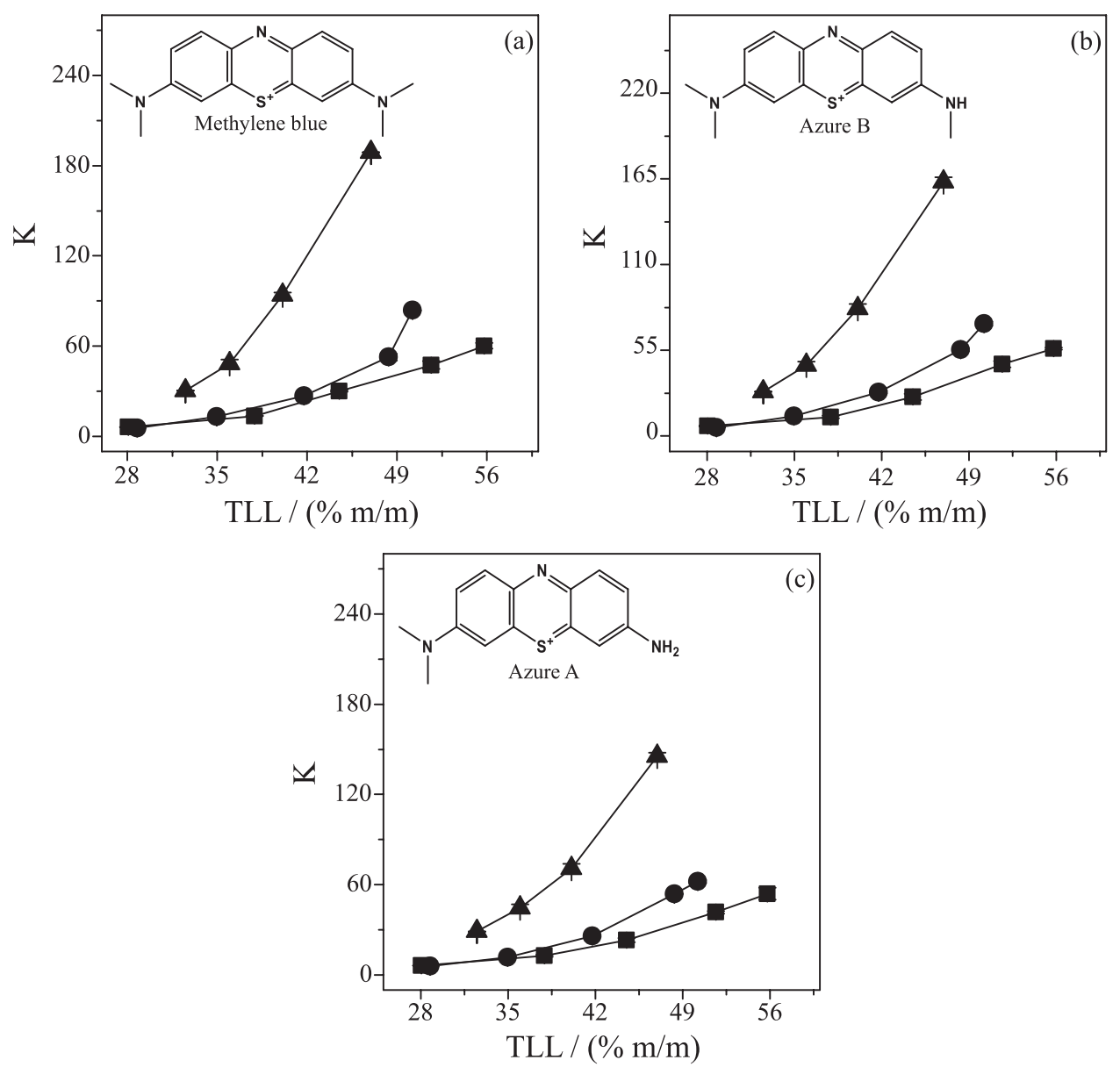

Figure 11. Anion effect on $\mathrm{K}$ values for the (a) MB; (b) AZB; (c) and AZA partition in the PEO $1500+\mathrm{Na}_{2} \mathrm{C}_{4} \mathrm{H}_{4} \mathrm{O}_{6}+\mathrm{H}_{2} \mathrm{O}(\bullet) ; \mathrm{PEO} 1500+\mathrm{Na}_{3} \mathrm{C}_{6} \mathrm{H}_{5} \mathrm{O}_{7}+$ $\mathrm{H}_{2} \mathrm{O}(\boldsymbol{\square})$; and PEO $1500+\mathrm{Na}_{2} \mathrm{SO}_{4}+\mathrm{H}_{2} \mathrm{O}(\boldsymbol{\Delta})$ ATPSs at $25^{\circ} \mathrm{C}$.

Table 4. Thermodynamic parameters of phenothiazine dye transfer obtained for PEO $1500+\mathrm{Na}_{2} \mathrm{C}_{4} \mathrm{H}_{4} \mathrm{O}_{6}+\mathrm{H}_{2} \mathrm{O}$ (TLL: $41.74 \% \mathrm{~m} / \mathrm{m}$ ), PEO $1500+\mathrm{Na}_{3} \mathrm{C}_{6} \mathrm{H}_{5} \mathrm{O}_{7}+\mathrm{H}_{2} \mathrm{O}$ (TLL: $38.00 \% \mathrm{~m} / \mathrm{m}$ ) and PEO $1500+\mathrm{Na}_{2} \mathrm{SO}_{4}+$ $\mathrm{H}_{2} \mathrm{O}$ (TLL: $40.10 \% \mathrm{~m} / \mathrm{m}$ ) ATPSs at $25^{\circ} \mathrm{C}$

\begin{tabular}{|c|c|c|c|}
\hline & $\mathrm{C}_{4} \mathrm{H}_{4} \mathrm{O}_{6}{ }^{2-}$ & $\mathrm{C}_{6} \mathrm{H}_{5} \mathrm{O}_{7}{ }^{3-}$ & $\mathrm{SO}_{4}{ }^{2-}$ \\
\hline \multicolumn{4}{|c|}{ MB } \\
\hline$\Delta_{\mathrm{tr}} \mathrm{G}^{\circ} /\left(\mathrm{kJ} \mathrm{mol}^{-1}\right)$ & $-8.17 \pm 0.09$ & $-6.47 \pm 0.01$ & $-11.26 \pm 0.05$ \\
\hline$\Delta_{\mathrm{tr}} \mathrm{H}^{\circ} /\left(\mathrm{kJ} \mathrm{mol}^{-1}\right)$ & $-23.0 \pm 0.6$ & $-11.4 \pm 0.3$ & $-25 \pm 1$ \\
\hline $\mathrm{T} \Delta_{\mathrm{tr}} \mathrm{S}^{\circ} /\left(\mathrm{kJ} \mathrm{mol}^{-1}\right)$ & $-14.8 \pm 0.6$ & $-4.93 \pm 0.3$ & $-13.74 \pm 1$ \\
\hline \multicolumn{4}{|c|}{ AZB } \\
\hline$\overline{\Delta_{\mathrm{tr}} \mathrm{G}^{\circ} /\left(\mathrm{kJ} \mathrm{mol}^{-1}\right)}$ & $-8.26 \pm 0.07$ & $-6.2 \pm 0.2$ & $-10.92 \pm 0.09$ \\
\hline$\Delta_{\mathrm{tr}} \mathrm{H}^{\circ} /\left(\mathrm{kJ} \mathrm{mol}^{-1}\right)$ & $-31 \pm 1$ & $-25 \pm 1$ & $-35 \pm 1$ \\
\hline $\mathrm{T} \Delta_{\mathrm{tr}} \mathrm{S}^{\circ} /\left(\mathrm{kJ} \mathrm{mol}^{-1}\right)$ & $-23 \pm 1$ & $-19 \pm 1$ & $-24 \pm 1$ \\
\hline \multicolumn{4}{|c|}{ AZA } \\
\hline$\Delta_{\mathrm{tr}} \mathrm{G}^{\circ} /\left(\mathrm{kJ} \mathrm{mol}^{-1}\right)$ & $-8.08 \pm 0.09$ & $-6.3 \pm 0.1$ & $-10.6 \pm 0.1$ \\
\hline$\Delta_{\mathrm{tr}} \mathrm{H}^{\circ} /\left(\mathrm{kJ} \mathrm{mol}^{-1}\right)$ & $-33.3 \pm 0.9$ & $-24.0 \pm 0.5$ & $-35 \pm 1$ \\
\hline $\mathrm{T} \Delta_{\mathrm{tr}} \mathrm{S}^{\circ} /\left(\mathrm{kJ} \mathrm{mol}^{-1}\right)$ & $-25.2 \pm 0.9$ & $-17.7 \pm 0.5$ & $-24 \pm 1$ \\
\hline
\end{tabular}

Experimental measure of thionin acetate (TA) in PEO $1500+\mathrm{Na}_{2} \mathrm{C}_{4} \mathrm{H}_{4} \mathrm{O}_{6}+$ $\mathrm{H}_{2} \mathrm{O}$ and PEO $1500+\mathrm{Na}_{3} \mathrm{C}_{6} \mathrm{H}_{5} \mathrm{O}_{7}+\mathrm{H}_{2} \mathrm{O}$ ATPSs at $25^{\circ} \mathrm{C}$ was not possible due precipitation. $\mathrm{MB}$ : methylene blue; $\Delta_{\mathrm{tr}} \mathrm{G}^{\circ}$ : dye transfer standard Gibbs free energy change; $\Delta_{t 1} \mathrm{H}^{\circ}$ : dye transfer standard enthalpy change; $\Delta_{\mathrm{tr}} \mathrm{S}^{\circ}$ : dye transfer standard entropy change; AZB: azure B; AZA: azure A.

\section{Supplementary Information}

Supplementary information (chemical structures of the phenothiazine dyes (Figure S1); maximum fluorescence intensity of $\mathrm{MB}, \mathrm{AZB}$ and $\mathrm{AZA}$ dyes as function of concentration in $\mathrm{H}_{2} \mathrm{O}$ at $25^{\circ} \mathrm{C}$ (Figure $\mathrm{S} 2$ ); $\mathrm{H}_{\text {dye }}^{\mathrm{E}}$ values for AZB and AZA dyes as a function of the dye concentration in top and bottom phases of the PEO $1500+\mathrm{Li}_{2} \mathrm{SO}_{4}+\mathrm{H}_{2} \mathrm{O}$ ATPS at $25^{\circ} \mathrm{C}$ (Figure S3); tables containing $\mathrm{K}$ and $\Delta_{\mathrm{tr}} \mathrm{G}^{\circ}$ values of MB, AZB, AZA and TA, for five TLL of the PEO $1500+\mathrm{MgSO}_{4}+\mathrm{H}_{2} \mathrm{O}$ ATPS at $25^{\circ} \mathrm{C}$ (Table S1); K, $\Delta_{\mathrm{tr}} \mathrm{G}^{\circ}, \Delta_{\mathrm{tr}} \mathrm{H}^{\circ}$ and $\mathrm{T} \Delta_{\mathrm{tr}} \mathrm{S}^{\circ}$ values of MB, AZB, AZA, and TA, for five TLLs of the PEO $1500+\mathrm{Li}_{2} \mathrm{SO}_{4}+\mathrm{H}_{2} \mathrm{O}$ ATPS at $25{ }^{\circ} \mathrm{C}$ (Table S2); $\mathrm{K}$ and $\Delta_{\mathrm{tr}} \mathrm{G}^{\circ}$ values of $\mathrm{MB}, \mathrm{AZB}, \mathrm{AZA}$ and TA, for five TLLs of the PEO $1500+\mathrm{Na}_{2} \mathrm{SO}_{4}+\mathrm{H}_{2} \mathrm{O}$ ATPS at $25^{\circ} \mathrm{C}$ (Table S3); $\mathrm{K}$ values and $\Delta_{\mathrm{tr}} \mathrm{G}^{\circ}$ of MB, AZB and AZA, for five TLLs of the PEO $1500+\mathrm{Na}_{2} \mathrm{C}_{4} \mathrm{H}_{4} \mathrm{O}_{6}+$ $\mathrm{H}_{2} \mathrm{O}$ ATPS at $25^{\circ} \mathrm{C}$ (Table S4); and $\mathrm{K}$ and $\Delta_{\text {tr }} \mathrm{G}^{\circ}$ values of MB, AZB and AZA, for five TLLs of the PEO $1500+$ $\mathrm{Na}_{3} \mathrm{C}_{6} \mathrm{H}_{5} \mathrm{O}_{7}+\mathrm{H}_{2} \mathrm{O}$ ATPS at $25^{\circ} \mathrm{C}$ (Table S5)) is available free of charge at http://jbcs.sbq.org.br as PDF file. 


\section{Acknowledgments}

This work was supported by the Coordenação de Aperfeiçoamento de Pessoal de Nível Superior (CAPES), Conselho Nacional de Desenvolvimento Científico e Tecnológico (CNPq), and Fundação de Apoio à Pesquisa de Minas Gerais (FAPEMIG).

\section{Author Contributions}

Yara L. Coelho was responsible for the conceptualization, data curation, formal analysis, investigation, methodology, visualization, writing original draft, review and editing; Álvaro J. P. Agudelo for the data curation, formal analysis, investigation, writing review and editing; Guilherme M. D. Ferreira for the conceptualization, data curation, formal analysis, methodology, visualization, writing review and editing; Gabriel M. D. Ferreira for the data curation, formal analysis, investigation, methodology, writing review and editing; Alan S. B. de Castro for the data curation, formal analysis, investigation, writing review and editing; Eliara A. Hudson for the data curation, formal analysis, investigation, methodology, writing review and editing; Ana Clarissa S. Pires for the conceptualization, funding acquisition, resources, supervision, visualization, writing original draft, review and editing, Luis H. M. da Silva for the conceptualization, funding acquisition, investigation, methodology, project administration, resources, supervision, visualization, writing original draft, review and editing.

\section{References}

1. Albertsson, P.-A.; Nature 1958, 182, 709.

2. Duarte, A. W. F.; Lopes, A. M.; Molino, J. V. D.; Pessoa, A.; Sette, L. D.; Sep. Purif. Technol. 2015, 156, 215.

3. Chow, Y. H.; Yap, Y. J.; Anuar, M. S.; Tejo, B. A.; Ariff, A.; Show, P. L.; Ng, E. P.; Ling, T. C.; J. Chromatogr. B 2013, 934, 71.

4. Akama, Y.; Ito, M.; Tanaka, S.; Talanta 2000, 53, 645.

5. Patrício, P. R.; Cunha, R. C.; Vargas, S. J. R.; Coelho, Y. L.; da Silva, L. H. M.; da Silva, M. C. H.; Sep. Purif. Technol. 2016, 158, 144.

6. Fischer, I.; Morhardt, C.; Heissler, S.; Franzreb, M.; Langmuir 2012, 28, 15789.

7. Khripin, C. Y.; Fagan, J. A.; Zheng, M.; J. Am. Chem. Soc. 2013, 135, 6822 .

8. de Alvarenga, J. M.; Fideles, R. A.; da Silva, M. V.; Murari, G. F.; Taylor, J. G.; de Lemos, L. R.; Rodrigues, G. D.; Mageste, A. B.; Fluid Phase Equilib. 2015, 391, 1.

9. Ferreira, A. M.; Coutinho, J. A. P.; Fernandes, A. M.; Freire, M. G.; Sep. Purif. Technol. 2014, 128, 58.
10. Akama, Y.; Tong, A.; Ito, M.; Tanaka, S.; Talanta 1999, 48, 1133.

11. Tong, A. J.; Dong, J. J.; Li, L. D.; Anal. Chim. Acta 1999, 390, 125.

12. Penido, J. A.; Mageste, A. B.; Martins, P. L.; Ferreira, G. M. D.; J. Mol. Liq. 2019, 293, 111501.

13. Borges, G. A.; Silva, L. P.; Penido, J. A.; de Lemos, L. R.; Mageste, A. B.; Rodrigues, G. D.; J. Environ. Manage. 2016, 183, 196.

14. Mageste, A. B.; Senra, T. D. A.; da Silva, M. C. H.; Bonomo, R. C. F.; da Silva, L. H. M.; Sep. Purif. Technol. 2012, 98, 69.

15. Mageste, A. B.; de Lemos, L. R.; Ferreira, G. M. D.; da Silva, M. D. C. H.; da Silva, L. H. M.; Bonomo, R. C. F.; Minim, L. A.; J. Chromatogr. A 2009, 1216, 7623.

16. Junqueira, C. M.; Cabral, D. S.; Penido, J. A.; Mageste, A. B.; Virtuoso, L. S.; Fluid Phase Equilib. 2018, 478, 14.

17. Merchuk, J. C.; Andrews, B. A.; Asenjo, J. A.; J. Chromatogr. $B$ 1998, 711, 285.

18. Shu, Y.; Gao, M.; Wang, X.; Song, R.; Lu, J.; Chen, X.; Talanta 2016, 149,6 .

19. Silva, M. F. F.; Fernandes-Platzgummer, A.; Aires-Barros, M. R.; Azevedo, A. M.; Sep. Purif. Technol. 2014, 132, 330.

20. Almeida, M. R.; Passos, H.; Pereira, M. M.; Lima, Á. S.; Coutinho, J.A. P.; Freire, M. G.; Sep. Purif. Technol. 2014, 128, 1.

21. Ferreira, G. M. D.; Ferreira, G. M. D.; Maldaner, A. O.; da Silva, L. H. M.; Hespanhol, M. C.; Fluid Phase Equilib. 2020, 506, 112367.

22. da Silva, L. H. M.; da Silva, M. C. H.; Júnior, J. A.; Martins, J. P.; Coimbra, J. S. R.; Minim, L. A.; Sep. Purif. Technol. 2008, $60,103$.

23. Alcântara, L. A. P.; Amaral, I. V.; Bonomo, R. C. F.; da Silva, L. H. M.; da Silva, M. C. H.; Minim, V. P. R.; Minim, L. A.; Food Bioprod. Process. 2014, 92, 409.

24. Rengifo, A. F. C.; Ferreira, G. M. D.; Ferreira, G. M. D.; da Silva, M. C. H.; Rezende, J. P.; Pires, A. C. S.; da Silva, L. H. M.; Food Bioprod. Process. 2016, 100, 361.

25. Wainwright, M.; Photodiagn. Photodyn. Ther. 2005, 2, 263.

26. How, S. C.; Cheng, Y. H.; Lo, C. H.; Lai, J. T.; Lin, T. H.; Bednarikova, Z.; Antosova, A.; Gazova, Z.; Wu, J. W.; Wang, S. S. S.; Int. J. Biol. Macromol. 2018, 119, 1059.

27. Jiang, Z.; Duong, T. Q.; Brain Circ. 2016, 2, 48.

28. Vennerstrom, J. L.; Makler, M. T.; Angerhofer, C. K.; Williams, J. A.; Antimicrob. Agents Chemother. 1995, 39, 2671.

29. Rajan, D.; Ilanchelian, M.; Int. J. Biol. Macromol. 2018, 113, 1052.

30. Martins, J. P.; Carvalho, C. D. P.; da Silva, L. H. M.; Coimbra, J. S. D. R.; da Silva, M. D. C. H.; Rodrigues, G. D.; Minim, L. A.; J. Chem. Eng. Data 2008, 53, 238.

31. Patrício, P. R.; Mageste, A. B.; de Lemos, L. R.; de Carvalho, R. M. M.; da Silva, L. H. M.; da Silva, M. C. H.; Fluid Phase Equilib. 2011, 305, 1. 
32. Leo, A.; Hansch, C.; Elkins, D.; Chem. Rev. 1971, 71, 525.

33. Homem-de-Mello, P.; Mennucci, B.; Tomasi, J.; da Silva, A. B. F.; Theor. Chem. Acc. 2005, 113, 274.

34. Tafulo, P. A. R.; Queirós, R. B.; González-Aguilar, G.; Spectrochim. Acta, Part A 2009, 73, 295.

35. Florence, N.; Naorem, H.; J. Mol. Liq. 2014, 198, 255.

36. Yuzhakov, V. I.; Russ. Chem. Rev. 1979, 48, 2007.

37. Rabinowitch, E.; Epstein, L. F.; J. Am. Chem. Soc. 1941, 63, 69.

38. Tardivo, J. P.; Del Giglio, A.; de Oliveira, C. S.; Gabrielli, D. S.; Junqueira, H. C.; Tada, D. B.; Severino, D.; Turchiello, R. F.; Baptista, M. S.; Photodiagn. Photodyn. Ther. 2005, 2, 175.

39. Santin, L. R. R.; dos Santos, S. C.; Novo, D. L. R.; Bianchini, D.; Gerola, A. P.; Braga, G.; Caetano, W.; Moreira, L. M.; Bastos, E. L.; Romani, A. P.; de Oliveira, H. P. M.; Dyes Pigm. 2015, $119,12$.

40. Jockusch, S.; Turro, N. J.; Tomalia, D. A.; Macromolecules 1995, 28, 7416.

41. da Silva, J. S.; Junqueira, H. C.; Ferreira, T. L.; Electrochim. Acta 2014, 144, 154.
42. Rogers, R. D.; Bauer, C. B.; J. Chromatogr. B: Anal. Technol. Biomed. Life Sci. 1996, 680, 237.

43. Kumar, A.; Rai, G.; J. Phys. Chem. B 2014, 118, 4160.

44. Levine, I. N.; Physical Chemistry, $6^{\text {th }}$ ed.; McGrawHill: Boston, 2009.

45. Frenking, G.; Wichmann, K.; Fröhlich, N.; Grobe, J.; Golla, W.; Le Van, D.; Krebs, B.; Läge, M.; Organometallics 2002, 21, 2921.

46. da Silva, L. H. M.; da Silva, M. C. H.; de Aquino, R. A. N.; Francisco, K. R.; Cardoso, M. V. C.; Minim, L. A.; Coimbra, J. S. R.; J. Phys. Chem. B 2006, 110, 23540.

47. Johansson, H. O.; Karlström, G.; Tjerneld, F.; Haynes, C. A.; J. Chromatogr. B: Anal. Technol. Biomed. Life Sci. 1998, 711, 3.

48. da Silva, L. H. M.; Loh, W.; J. Phys. Chem. B 2000, 104, 10069. 49. da Silva, L. H. M.; da Silva, M. C. H.; Francisco, K. R.; Cardoso, M. V. C.; Minim, L. A.; Coimbra, J. S. R.; J. Phys. Chem. B 2008, 112, 11669. 